\title{
EL LOPISMO INGLÉS DEL SIGLO XVIII: SIR JOHN TALBOT DILLON (1739-1805) Y WILLIAM HAYLEY (1745-1820)
}

\author{
Mercedes Comellas \\ Universidad de Sevilla \\ mcomellas@us.es
}

\author{
ANTONio SÁnChez JimÉneZ \\ Université de Neuchâtel \\ antonio.sanchez@unine.ch
}

$\square$ s comúnmente sabido que la participación inglesa en la Guerra de la Independencia contra Napoleón (1808-1814), llamada en Inglaterra Peninsular War, despertó en este país un gran interés por España, y que este interés fomentó viajes, nuevas ideas e incluso diversos estudios sobre nuestra literatura. Sin embargo, es menos conocido que estos hispanistas postnapoleónicos contaban con ilustres precedentes dieciochescos que también visitaron nuestro país en la segunda mitad del XVIII (Peers 1940, II: 390-391)1. Estos escritores contribuyeron a formar las opiniones inglesas sobre las letras españolas e incluso anuncian el romanticismo al propagar ideas herderianas sobre la literatura, por más que las nuevas concepciones convivan en sus textos con las nociones propias de una

\footnotetext{
1 «Parece que aquella nación se ha empeñado modernamente en describir la España con particular interés» (Azara 1782: s.p.), aunque muchos, como el Swinburne (1787) que critica Azara, se dejaran llevar más bien por el deseo de zaherir las costumbres hispanas y por el afán de subrayar los aspectos exóticos de nuestro país: «Viajando por lo demás en España jamás omite ninguna de las importantísimas observaciones que se deben hacer sobre mesoneros y mesoneras, sus trajes, etc. No se le olvidan las guitarras y el fandango, ni el citar continuamente a Don Quijote y Gil Blas, que son las dos fuentes perennes de su erudición» (Azara 1782: s.p.). En cualquier caso, la abundancia de relatos de viajes por España en este último cuarto del siglo XVIII llegó a convertirse en un tópico del exordio de este tipo de obras: «So many English travelers have of late published their remarks in their respective tours of Spain, that it is not without the utmost deference that the present letters are offered to the public» (Dillon 1781: iii).
}

Edad de Oro, XXXVII (2018), pp. 247-285, ISSN: 0212-0429 - ISSNe: 2605-3314 
educación clasicista. Para incitar al estudio de este corpus, nuestro trabajo se va a centrar en las opiniones sobre Lope de Vega de dos hispanistas dieciochescos, el viajero y polígrafo irlandés John Talbot Dillon (1739-1805) y el poeta inglés William Hayley (1745-1820), textos relacionados que entran en diálogo, pues el de Hayley es, en parte, una respuesta al de Dillon. Para llevar a cabo el análisis de ambas obras, examinaremos en primer lugar el contexto en que se compusieron, es decir, la tradición de viajes ingleses a la península en el siglo xvIII y las opiniones de sus autores sobre las letras hispanas. A continuación, nos centraremos ya en la hispanofilia de los dos escritores que nos interesan, analizando en detalle la visión de Lope de Vega que traslucen, para lo que contrastaremos sus fuentes y criterios. Finalmente, y tras una conclusión acerca del sentido e importancia de estos textos en su contexto europeo, ofreceremos en apéndice una traducción de los mismos, para que los especialistas los puedan comparar con los trabajos de los célebres lopistas ingleses del siglo xIX (Lord Holland, Shelley, etc.).

\section{Los PRECEDENTES: VIAJEROS INGLESES EN LA ESPAÑa DieCIOCHESCA}

Cuando los libros de Dillon y Hayley salieron de la imprenta, la moda del viaje a España apenas alboreaba en Inglaterra, aunque desde muy pronto esta joven tendencia mostró un gran potencial editorial. Es lo que sugería en 1771 la Critical Review al quejarse de la abundancia de relatos de viajes por Francia e Italia y al ponderar, en cambio, los dedicados a nuestro país. Según el articulista, las obras de los viajeros que acudían a Francia e Italia eran tantas que habían saturado las librerías inglesas; por el contrario, los relatos de viajes por España resultaban novedosos. De ellos, y atendiendo a las demandas de los lectores, la Critical Review reseñó los Travels through Portugal and Spain de Twiss (1775), los Travels through Spain y las Letters from an English Traveller in Spain de Dillon (1780 y 1781), así como el Journey through Spain in the Years 1786 and 1787 de Townsend (1791) (Turner 2001: 129). La obra de Dillon se enmarca así en una nueva corriente viajera que por fin cruzaba los Pirineos y de la que habían dado precoz muestra autores como Philip Thicknesse, A Year's Journey through France and Part of Spain (1777), William Dalrymple, Travels through Spain and Portugal in 1774 (1777), o el ya mencionado Henry Swinburne, Travels through Spain in the Years 1775 and 1776 (1779).

Según han estudiado críticos como Fernández Herr (1973), Robertson (1976), Bacigalupo (1979), Guerrero (1988; 1989; 1990), Freixa (1993) y Bolufer Peruga (2003), el número de viajeros británicos que recorrieron la península, muy escaso hasta mediados de siglo, aumentó considerablemente a partir 1760. La afluencia fue especialmente considerable desde los años anteriores a la Guerra 
de Independencia americana hasta finales de siglo, momento en que se verá interrumpida por la Revolución francesa. En este último tercio del xvIII, los ingleses viajan a España por intereses económicos, sobre todo cuando Inglaterra, perdidas las colonias americanas, trata de ganar prestigio y espacio comercial en Europa frente al dominio francés (Guerrero 1989: 13-28). En parte como consecuencia de esta rivalidad con los viajeros galos, la mirada británica sobre nuestro país se distancia de la mucho más acerba y rigurosa de los franceses, centrada en la leyenda negra y amiga de incidir hasta la exageración en el atraso español, como hicieron desde Aulnoy a Voltaire y desde Montesquieu a Masson de Morvilliers. Por el contrario, los irlandeses, escoceses e ingleses no se vieron tan limitados por ese punto de vista y tradición textual, y fueron renovando paulatinamente la visión de España al contrastar los estereotipos con sus propias impresiones. Gracias a ellos, la imagen negativa de España fue transformándose y pudo extender, particularmente en Alemania (donde la mayoría de estos textos conoció traducción temprana $)^{2}$, una visión novedosa que fue preparando la romántica. Esto es: en estos autores británicos encontramos las primeras referencias a un cambio de paradigma en la visión de España y de su cultura que servirán a la construcción de la nueva imagen romántica de nuestro país (Hönsch 2000).

En cuanto a la opinión que les merecía concretamente la literatura española, Bacigalupo piensa que «Golden Age literature did not always meet with the Englishmen's approval, precisely for the reason that they lived in an age which took a dismal view of "enthusiasm", whether in religion or aesthetics» (1978: 131). Sin embargo, la lectura atenta de los textos demuestra que los juicios de estos inquisitivos caballeros no fueron siempre negativos; es más, en no pocas ocasiones resultaron claramente ponderativos. Refiriéndonos ya en particular al teatro español, los primeros comentarios de estos viajeros ilustrados ingleses los encontramos en el volumen de Edward Clarke, Letters concernig the Spanish Nation: written at Madrid during the Years 1760 and 1761 (1863), cuyo capitulo IV se titula «State of Literature, Letters, and Men of Learning in Spain» y ofrece un particular «Catalogue of Spanish Authors» (1763: 49-90). La lista de poetas y dramaturgos comienza por Ercilla, al que siguen Esquilache, Antonio Lofraso (que no es español sino sardo, cuyos Diez libros de Fortuna de Amor habían sido reeditados lujosamente en Londres, 1740), Pineda (probablemente el sefardí londinense Pedro Pineda, editor de Lofraso; o bien el humanista Juan de Pineda),

$2 \quad$ La obra de George Glas cuenta con dos ediciones en alemán, publicadas en Leipzig en 1777 y 1789. También fue traducida y editada en Leipzig la de Richard Twiss (1777) y después las de Townsend (Reise durch Spanien in den Jahren 1786 und 1787, Leipzig, Weidmann, 1792) y Dillon (Reise durch Spanien, welche wichtige Beobachtungen aus der Naturgeschichte. [...] aus Don Guillermo Bowles Einleitung, Leipzig, 1782), con considerables diferencias con respecto al original. 
Nebrija y «the two Vega's, Garcilasso and Lopez». El segundo «López», esto es, Lope de Vega (al que siempre llama «López de Vega Carpio» ${ }^{3}$ ), se compara — siguiendo a Voltaire - con Shakespeare: «López de Vega Carpio, as Voltaire tells us, comes the nearest to our Shakespeare». Con ello, el Fénix queda ya señalado como uno de nuestros más eximios autores, al nivel del más elevado genio inglés ${ }^{4}$. Aunque hoy muchos podamos compartir esta opinión, lo cierto es que lo arbitrario de la lista de Clarke coincide con lo poco atinado de los restantes comentarios: como algunos años después le criticará Dieze, Clarke no sabía español ni conocía nuestro teatro, y, además de falsa, su opinión era arrogante, pues se atrevía a enjuiciar todo el teatro español habiendo visto un solo auto sacramental: «[seine] Nachricht von der Bühne, die höchst elend, falsch und unvollkommen ist» (Dieze 1769: 102 y 297-298).

Un año más tarde se publica otro volumen cuya opinión sobre el teatro español resulta mucho más positiva. George Glas, en $A$ Description of the Canary Islands de 1764 (añadida a la traducción al inglés del manuscrito de Juan de Abreu Galindo), afirma que «the Spaniards have succeded better in dramatic perfomances than any other Europeans» (1764: 302). Su lista de ingenios es mucho menos chocante para nuestros hábitos que la de Clarke, aunque demuestra clara distancia con la que después se confirmará como canónica: incluye a Juan de Matos Fragoso, José Cañizares, Agustín de Salazar, Luis Vélez de Guevara, Antonio Solís, Agustín Moreto, Pedro Calderón y Lope de Vega, en quienes se detiene subrayando especialmente la importancia de Calderón («but of all these Don Pedro Calderon is most esteemed by the Spaniards; and not without reason, for his plays are inferior to none that have yet appeared on any stage in Europe») y de Lope, comparado de nuevo con Shakespeare, en lo que a estas alturas se ha transformado ya en un lugar común: «Lopez de Vega Carpio has been by many justly compared to our Shakespeare» (1764: 302), o también con Corneille, que según Glas tomó de una de las obras del Fénix el plan de su $\mathrm{Cid}^{5}$. Tras la comparación de ambos textos,

3 En descargo de Clarke, otros viajeros incurrieron en ese error. Fue el caso, ya en el siglo xVII, de Cassiano dal Pozzo (2004: 151 y 262).

4 Voltaire compara a Shakespeare con Corneille y Lope: «Lope de Véga en est un grand exemple. Il était précisément ce que fut Shakespeare en Angleterre, un composé de grandeur et d'extravagance, quelquefois digne modèle de Corneille» (1880: 364). A esta primera remiten todas las comparaciones españolas posteriores, desde las de Juan Andrés a las Cadalso, comparaciones que acompañaron, según Pujante (2001), a la recepción de Shakespeare en España. Para Menéndez Pelayo (2012: 947), la primera comparación española la hizo Joseph Calderón de la Barca, director del Memorial Literario y «partidario de la cultura inglesa», en una «Carta apologética en defensa de Fr. D. Félix Lope de Vega Carpio y otros poetas cómicos españoles» que incluyó en la publicación (1796: 305-322).

5 Hoy la crítica concuerda en atribuir Las mocedades del Cid a Guillén de Castro, no a Lope. 
afirma el inglés, «it will be hard to determine which of the two is the most excellent» (1764: 303). Dado que «Lopez De Vega's dramatic writings are extremely scarce, and difficult to be got even in Spain [...] and because the English reader's curiosity may be excited by hearing him compared to Shakespeare», Glas incluye como demostración de su fuerza dramática un largo fragmento de El mayorazgo dudoso en su lengua original que después traduce al inglés con bastante libertad ${ }^{6}$.

Las noticias sobre teatro y sobre Lope de Vega siguen creciendo en la relación de Giuseppe Marco Antonio Baretti (1719-1789), turinés afincado en Londres cuyo Journey from London to Genoa, through England, Portugal, Spain, and France de 1770 fue saludado por Samuel Johnson (Bacigalupo 1978; Bolufer 2003: n. ${ }^{\circ}$ 19) y conoció una importante difusión. En el tercero de los volúmenes de esta obra Baretti trata de los escritores españoles, de los que demuestra conocer a los más importantes; entre los dramaturgos, «the two that proved most voluminous are Lope de Vega Carpio, and Calderón de Barca [sic]. Lope de Vega, they say, has left in print more than three hundred dramatic pieces, out of twice, as many that he had written. Another imagination so fertile in plots and characters, has never existed» (1770: III, 19-20). Sin entrar a examinar críticamente a estos autores (pues «to sit in judgment upon the theatrical performances of a foreign nation, requires much more knowledge of its language, manners, and customs, than comes to my share with regard to the Spaniards»), sí reconoce sus faltas:

As to the other plays of Lope de Vega and Calderon, many are the things in them that a critic might easily find fault with. They both disgust me often with the prolixity of their speeches, with their superfluous descriptions, with a medly of tragical and comical ideas, with their frequency of far-fetched conceits, with their bombast and fustian interlarded with puns and quibbles, and above all — with their frequent associations of real and ideal personages-.

Pero todos aquellos vicios no ensombrecen las extraordinarias cualidades que sus obras poseen, y que Baretti cifra sobre todo en el genio poético, la originalidad y la invención, la variedad de caracteres y sentimientos, y la fuerza y facilidad de la expresión en verso:

In spight however of their numerous oddities, incongruities, and absurdities, I must own that I cannot 'easily lay down their books when I have once begun to read, and am so far an admirer of these two poets, as to rank them both in the very first class of poetical geniuses. The copiousness and originality of their invention, their artfulness in entangling and disentangling their plots, their vast variety of characters, their numberless sentiments, the force and elegance of their expression, their

$6 \quad$ Sobre la traducción, véase Castillo (2003: 49-50). 
facility of versification, and several other of their excellences, sill me often with such an enthusiasm, as to make me cross rapidly over the ocean of their errors, and forget the frigid dictates of sober reason (1770, III: 26-27).

Páginas más adelante Baretti hace referencia a la dificultad para coleccionar las obras completas del Fénix y a los esfuerzos del infante don Luis, hermano del rey, por comprar y reunir todos los volúmenes impresos en diferentes países, colección que no posee salvo el duque de Medina Sidonia, el más reputado de los nobles en cuestiones de letras (1770: 43-45). Pero lo más interesante de las apreciaciones de Baretti es que ya presenta las comedias españolas como antídoto frente a la sequedad y frialdad de las obras neoclásicas de moda entre ingleses y franceses. Poco antes había citado las críticas de Voltaire a Goldoni como demostración de que los franceses no tienen criterio alguno enjuiciando la literatura italiana, y termina animando a Voltaire y sus secuaces a estudiar a Lope y Calderón para descubrir lo que es poderoso y natural, estimular sus «cold and barren imaginations» (1770: III, 27), e incitando a los lectores a olvidar esas reglas «about which the French make so much noise» (1770: III, 34):

Indeed the present race of play-wrights in France and England, the driest and coldest that ever any theatrical age produced, instead of neglecting or contemning the dramatic compositions of Spain, would not do amiss to read many of them, especially, those of [Lope] de Vega and Calderon, not to imitate them at all, but to warm and fecundate their own cold and barren imaginations (Baretti 1770, III: 27).

Aunque no en este escrito, también Baretti asociará a Lope de Vega con Shakespeare en su Discours sur Shakespeare et sur Monsieur de Voltaire, producido en respuesta al de Voltaire de 1776 ante la Academia Francesa, un ataque a Shakespeare al que Baretti responde afirmando la autoridad de la experiencia frente a la de las reglas y recurriendo a los dos modelos antineoclásicos, el inglés y el español: «Qu'Aristote dise ce qu'il veut, j'oppose à son autorité l'expérience de Shakespeare, de Lope de Vega, et de plusieurs autres, qui nous ont fait voir le contraire» (Baretti 1972, II: 548). Por tanto, comprobamos que ya en los años setenta del siglo XVIII Lope se ha asentado en Inglaterra como un ingenio comparable a Shakespeare y como un arma arrojadiza en la batalla sobre la poética neoclásica. Las obras — de Clarke, Glas y Baretti- que avanzan estas ideas prepararían el terreno al siguiente viajero y sus correspondientes cartas, las Letters de Dillon, a las que vamos a dedicar una atención más detenida. 


\section{Sir John Talbot Dillon, Baronet (1739-1805)}

El interés por España de John Talbot Dillon parece haber nacido ligado a las ciencias naturales y al trabajo de un compatriota suyo, el naturalista irlandés William Bowles (1705-1780) $)^{7}$. A su vez, el hispanismo de Bowles se remonta a una iniciativa del célebre marino y expedicionario español Antonio de Ulloa, como cuenta el propio interesado, Bowles, en las líneas que siguen:

Estando yo en París el año 1752 hice por casualidad conocimiento con don Antonio de Ulloa, comendador de Ocaña, en la Orden de Santiago, que ahora es jefe de escuadra de la Real Armada, autor de dos obras sobre América. Convidome a venir a España y, habiendo aceptado el partido que por su medio me ofreció el Ministerio, entré aquel mismo año al servicio de esta Corona. Llegado a Madrid, me dieron por discípulos y compañeros para mis viajes por la península a don José Solano, que hoy (en 1773) es gobernador de Santo Domingo, y don Salvador de Medina, que murió en California, donde la Corte le envió para observar el último paso de Venus por el disco del sol, y don Pedro Saura, abogado, que murió en Madrid. Los dos primeros servían en la Marina y habían viajado fuera de España (Bowles 1775: 1).

Los viajes y servicios a la corona de Bowles comenzaron ese mismo año, pues el 7 de julio el irlandés partía hacia Almadén (1775:2) con «la comisión de reparar la mina [...], que se había inutilizado por un incendio y no se hallaba en estado de surtir poco ni mucho azogue para las labores de las minas de América» (1775: «Al Rey», s.p.). El éxito de los desvelos de Bowles fue recompensado con un puesto permanente al servicio del rey, posición que le «proporcionó [la oportunidad de] visitar la mayor parte de las provincias de España y recoger una multitud de observaciones de historia natural» (1775: «Al Rey», s.p.). Estas fueron publicadas en 1775 con el título de Introducción a la historia natural y a la geografía fisica de España y se anunciaban como «la primera descripción física» de nuestro país (1775: «Al Rey», s.p.). Amén de pionero, el libro fue, por demás, exitosísimo. Se tradujo al francés al año siguiente (Flavigny 1776) y, tras morir Bowles, el diplomático y erudito José Nicolás de Azara, que había ayudado a Bowles con la primera edición (Azara 1782: s.p.), se encargó de dar a imprenta una segunda, corregida de su mano, que apareció en 1782. Al año siguiente, 1783, el célebre editor de las Obras de Garcilaso (Martín Puya 2014) y embajador español en Roma se ocupó también de comentar y aumentar la traducción italiana de Milizia (1783), que sigue siendo la versión más completa de la obra del irlandés.

Azara pone ya de relieve la relación existente entre los libros de Bowles (1775) y Dillon (1780), pues el sabio aragonés denuncia que, «en el fondo», la obra de este último

\footnotetext{
7 Para una biografía contemporánea de Bowles, ver Azara (1782: s.p.).
} 
es la de Bowles, en muchas compendiada, en otras comentada, y las más veces traducida, añadiendo algunas noticias de las aguas minerales de Trillo, tomadas de la obrita que publicó don Casimiro Gómez Ortega; otras de botánica extractadas de la Flora de don José Quer; y varias erudiciones sobre las bellas artes y manifacturas sacadas del Viaje de España de don Antonio Ponz (1782: s.p.).

El propio Azara desvela también la estructura turística del libro de Dillon, que pretendía funcionar como una «descripción de España que sirva de guía a los ingleses que quieran viajar por nuestro reino» (1782: s.p.). Quizás este énfasis explique por qué Dillon ameniza sus descripciones geográficas, botánicas y geológicas con noticias eruditas sobre antigüedades o bellas artes, que muchas veces Dillon recoge, como avanza Azara, de Ponz, a quien el irlandés cita con profusión.

En cualquier caso, este interés por las humanidades se dispara en la segunda obra sobre España de Dillon, que es la que nos interesa en este momento ${ }^{8}$ : las $L e$ tters from an English Traveller in Spain. En ellas Dillon ofrece una guía de viaje a España influida por la literatura nacional ${ }^{9}$, lo que, confiesa, le parece el único modo de contribuir con algo original a la ya poblada bibliografía sobre nuestro país. No en vano, afirma Dillon, «the mountain of Parnassus has not been visited by the curious traveler, and the Spanish muse hast tuned her lyre without being disturbed by the unhallowed step of the rambling stranger» (Dillon 1781: iii-iv).

Ya hemos visto que esta afirmación no es del todo precisa, y que existían algunos precedentes en las letras inglesas de esos años, aunque mucho más breves en su conjunto; más ambicioso, Dillon se lanza al trabajo con entusiasmo, y revisa la literatura española en catalán, latín, galaico-portugués, castellano y eusquera o «vascuense», tocando diversos hitos de su historia. Así, el irlandés comenta la poesía trovadoresca, la obra de Alfonso X el Sabio, la del arcipreste de Hita, la de la época de Juan II, la del Siglo de Oro («Golden Age») del quinientos (Dillon 1781: 158), y el declive - por contagio del mal gusto marinista italiano (1781: 202) - del siglo XVII, llegando incluso a tratar de figuras contemporáneas como Olavide o Mayans, del que hablaremos abajo. A modo de guía turístico, Dillon menciona los lugares de interés por los que pasa explicando siempre qué escritores de renombre habitaron o habitan en ellos, y qué obras han escrito sobre el

$8 \quad$ La obra de Dillon debió de tener una repercusión considerable. Las Letters de 1781 sirvieron a la paráfrasis (y en largos pasajes pura traducción) que se hizo al francés con el título de Essai sur la littérature espagnole, publicado anónimo en 1810 en París y que, para Tomasina Ross, en el prólogo a su traducción inglesa de Bouterwek de 1823, es un plagio directo de Dillon (Comellas 2017: 397). En particular el fragmento dedicado a Lope se reproduce en The Annual Register, or a View of the History, Politics, and Literature, for the Year 1781 («Sketch» 1800: 33-36).

9 En realidad, Dillon solo recorre y describe partes de Cataluña, Valencia, los alrededores de Madrid, Burgos y parte de Vizcaya. 
particular objeto de sus visitas. Así, el viaje a Barcelona le exige una excursión a Montserrat, y esta, la mención del Monserrate de Virués (1781: 13). De modo semejante, la Ciudad Condal facilita la mención de los trovadores o de la lucha de don Quijote con el caballero de la Blanca Luna (1781: 14), y la llegada a Valencia le lleva a hablar del gran Mayans, a quien conoce personalmente (1781: 34-37).

Como se puede observar, en las Letters Dillon demuestra conocer bastante bien nuestra literatura, pues, aunque el irlandés admite sus preferencias cervantinas, también rinde homenaje a textos menos conocidos (aunque recientemente editados en su día), como la Mosquea de Villaviciosa, o las obras del conde de Rebolledo y Luis de Ulloa Pereira (1781: iv y 175-177). De hecho, Dillon reconoce haber bebido de las fuentes y consejos de dos grandes eruditos españoles del momento como son Luis José Velázquez y Juan José López Sedano, tan influyente el primero por sus Orígenes de la poesía castellana (García Aguilar 2013) - cuya estructura sigue fielmente Dillon-, como por su Parnaso español el segundo. Este conocimiento lleva a Dillon a unir sus fuerzas a las de los defensores del valor de la cultura española, tema muy candente en la época (Checa Beltrán 1998: 321):

It has been said by a great and learned French writer that the Spaniards have but one book, and that one shews the ridicule of all the others ${ }^{10}$. How far such a general reflection appears strained and tinctured with national prejudice, I shall leave to others to consider. Wishing to reverse so severe a sentence, I now stand before the court of Apollo, and petition for a hearing. Can we avoid doing that justice to the surprising genius of Lope de Vega, the contemporary, and in a manner rival, of our immortal Shakespeare; or can we refuse encomiums to the learned and unfortunate Quevedo? (Dillon 1781: v).

Abajo nos referiremos en más detalle a esta polémica, así como a las menciones de Lope en Dillon, pues ahora debemos recordar que las Letters no sería la última obra que el irlandés dedicó a nuestro país. También produjo unos Sketches on the Art of Painting (1782), traducción de la carta de Mengs a su admirado Ponz sobre las pinturas conservadas en los palacios reales madrileños, y una History of the Reign of Peter the Cruel (1788), reinado que parecía interesarle especialmente porque le permitía describir «the various passions of the soul, the feelings of the human heart, and the agitated mind of those people whose country I have described» (1788: vii) y por la relación de Pedro I con la historia inglesa (1788: ix). Por último, Dillon dedicó sus desvelos a otro rey castellano ligado a Inglaterra: Alfonso VIII, protagonista de su Alphonso and Eleanora (1800).

10 Dillon alude aquí al célebre y polémico artículo «Espagne», que publicó en la Encyclopédie méthodique de 1782 de Nicolas Masson de Morvilliers. 
Pese a la intención panegírica de sus Letters, al comentar la obra del Fénix, Dillon se revela un clasicista que no puede menos que horrorizarse ante lo que percibe como excesos de la obra dramática lopesca ${ }^{11}$. Y es que, aunque reconozca el genio del Fénix, la visión de Lope que tiene Dillon está muy influida por las opiniones cervantinas sobre su rival: recordemos que en la España de la época había ya una disputa entre lopistas y cervantistas (López 1976: 459) y que Dillon seguía muy de cerca a uno de estos últimos ${ }^{12}$. Además, Dillon también se apoya en una lectura muy poco sutil del Arte nuevo de hacer comedias. Para Dillon, el teatro cervantino no pudo triunfar como merecía debido a que Lope se había ganado el favor del vulgo «indulging their versatile humour» (Dillon 1781: 242). De este modo, el genio descontrolado del Fénix acabó por corromper el teatro nacional, aunque este juicio negativo viene acompañado de la ya tópica comparación con Shakespeare

as another Shakespeare, Lope de Vega acquired universal admiration. The fecundity of his genius was so great, and his productions so rapid, that he did not give leisure to the public to distinguish the efforts of his genius from the wild sallies of intemperate fancy; nor could the several attacks of Cervantes, Villegas, Cristóbal de Mesa, and others, prevail against this favourite bard. His successors copied his defects without possessing his beauties (Dillon 1781: 243).

Es una opinión que reaparece en la semblanza de Lope que Dillon incluye en sus Letters como decimoquinta carta, cuyo contexto y contenido va a ocuparnos durante el resto de esta sección. La situación de la epístola en el libro resulta ya significativa: al llegar a Madrid, el autor escribe una serie de cartas sobre la poesía cortesana, comenzando con la del siglo xv (cortes de Juan II y Enrique IV) en la carta X y siguiendo con el Siglo de Oro, que Dillon sitúa en el siglo XVI, en la carta XI. A continuación, la carta XII se dedica al «Fourth Period and Decline of Spanish Poetry in the Seventeenth Century», que corresponde al arte barroco, con algunas salvedades que Dillon incluye, contrariamente a la cronología, en la carta correspondiente al siglo xvi: Cervantes, Quevedo y Lope. El declive barroco lo identifica el irlandés con tres cabezas de hidra: los conceptistas, contagiados por la extravagancia italiana, la poesía culta (Góngora, Villamediana) (1781:

11 Conviene recordar que en la España de la época se recibía de modo muy distinto la poesía no dramática y dramática del Fénix. Tanto Leandro Fernández de Moratín como Cadalso y Luzán alababan la primera, que Moratín proponía como modelo, junto a Garcilaso, para la poesía contemporánea (Sala Valldaura 2000: 164).

12 Los cervantistas se apoyaban en autores como Velázquez, cuyos Orígenes sigue muy de cerca Dillon al tratar la obra teatral de Lope a través de los juicios cervantinos (Velázquez 1754: 107-108). 
203-204) ${ }^{13}$ y Flos corruptores del arte dramático, entre los que le cabe su parte de culpa a Lope:

[They] violated all the laws of the drama and introduced innumerable defects on the stage, which have never been eradicated. Of these, Cristóbal de Virués, Lope de Vega, and Montalbán were the principal leaders, and were followed by Calderón, Salazar, Candamo, Zamora, and others who to the most glaring improprieties superadded a ridiculous bombast and affectation of language which became superlative intolerable and absurd (Dillon 1781: 203).

Estas críticas prosiguen en la carta XIV, consagrada a la historia del teatro español («Revolutions and Progress of the Spanish Drama»), que en la parte dedicada al surgimiento de la comedia nueva bebe claramente del prólogo a las Ocho comedias de Cervantes - que, recordemos de nuevo, también había usado Velázquez-y, por tanto, censura la decisión de Lope de adaptarse al gusto popular y de producir tanto que ${ }^{14}$, según Dillon «he did not give leisure to the public to distinguish the efforts of genius from the wild sallies of intemperate fancy» (1781: 243). Sin embargo, nuestro viajero irlandés sigue reconociendo siempre que el problema de Lope tiene que ver más con una decisión errada (abandonar a los clásicos y seguir los gustos del pueblo) que con una supuesta falta de talento ${ }^{15}$. Esta distinción se evidencia cuando Dillon comenta el estilo de los seguidores de Lope, y particularmente el de Calderón, autor que considera defectuoso, sobre inmoral ${ }^{16}$ :

His successors copied his defects without possessing his beauties; Calderón, who came after him, gave the finishing hand to the fatal plan of Lope, and with the same advantages of language and wit, perverted the minds of the people. His scenes are repeated triumphs of vice, in which the fair sex are taught to sacrifice everything to the impressions of love, despite the advice of tender parents, and yield to the insidious arts of seducers (Dillon 1781: 243-244).

13 Estas apreciaciones negativas de la poesía gongorina eran típicas de la recepción dieciochesca (Sala Valldaura 2000: 164).

14 La censura de la cercanía lopesca al gusto popular y al Arte nuevo de hacer comedias - que, veremos, usa Dillon - era tópica en la literatura española de la época (Sala Valldaura 2000: 165, 166, 168 y 170). Sobre el debate en torno al teatro lopesco en la España del siglo XVIII, véase también Sala Valldaura (2000: 172-185).

15 La comparación con Shakespeare evidencia que Dillon respetaba el talento de Lope. Además, había una tradición española al respecto, pues incluso sólidos detractores dieciochescos del teatro del Fénix, como Moratín padre, o su hijo, admitían el genio del madrileño (Sala Valldaura 2000: 174 y 184). Sobre estas opiniones de Moratín hijo, véase Entrambasaguas (1941).

16 Es una idea que coincide con la que Velázquez expresa — siguiendo, a su vez, a Blas Nasarre (1992: 90-91) — sobre Calderón (1754: 111-115). 
Sin embargo, la principal prueba del lopismo de Dillon está en la carta XV, que ofrece una semblanza del Fénix y un comentario extenso de su estilo y obras. Sus fuentes son la «Fama póstuma» de Pérez de Montalbán, la epístola A Claudio y el Arte nuevo, pero comete errores (llamar «poema» a la Arcadia, generalizar sobre los finales de las comedias lopescas) que nos hacen pensar que el irlandés no leyó mucho más. En cualquier caso, la estructura de su semblanza es clara: tras un exordio en que compara a Lope con Shakespeare ${ }^{17}$ y en que señala lo difícil que le resulta hacerle justicia a alguien que no escribe en la lengua de uno, Dillon relata la juventud del escritor, en la que resalta la influencia de su padre, Felices, también poeta, y las muestras tempranas de ingenio del niño. Se trata de un tópico propio del género de la biografía de artistas que también trae Montalbán (Hägg 2012: 6; Kris y Kurz 1987: 38) y que corresponde perfectamente con el retrato de Lope que trata de pintar Dillon: el de un genio inigualable ${ }^{18}$. A continuación, Dillon relata la formación de Lope (con don Jerónimo Manrique y en la Universidad de Alcalá) y el final de la juventud del autor: su matrimonio con Isabel de Urbina, el exilio a Valencia, la muerte de la dama y la participación en la Armada, en la que fallece el hermano del poeta. En todos estos puntos Dillon sigue a Montalbán, aunque añade algo de su cosecha: el contexto del duelo por el que se tuvo que exiliar el Fénix, que simplifica la acción trazada por Montalbán relacionando matrimonio y exilio. A continuación, Dillon relata fugazmente la madurez de Lope, contando su matrimonio con Juana de Guardo, la muerte de la dama y la ordenación del poeta, que vive en esta época su mayor celebridad, culminada por el doctorado en teología y el hábito de san Juan con que le recompensa Urbano VIII. En cuanto a la muerte del poeta, Dillon vuelve a simplificar el extenso relato de Montalbán, centrándose brevemente en las postrimerías del Fénix y algo más en sus exequias. Más parece interesarle la cuestión de la fama del autor, que enfatiza también señalando las

17 Ya hemos visto el contexto francés e inglés de esta comparación, que también adoptó, entre los críticos españoles del siglo XVIII, Antonio Eiximeno: «A no haber cerrado los ojos y tapádose los oídos a las reglas de los unitarios, ni Inglaterra hubiera tenido un Shakespeare, ni España un Lope de Vega» (Rossi 1967: 35).

18 El retrato de ese prodigioso genio infantil basado en la Fama póstuma de Pérez de Montalbán estaba regularmente extendido en la época, pues se encuentra ya en uno de los diccionarios enciclopédicos más importantes del XVIII alemán, el de Johann Burkhard Mencke, Compendiöses Gelehrten Lexicon (1715-1726: 1374-1375), donde el autor presenta a Lope como «ein vortreflicher Spanischer Poete», doctor en teología y guerrero («führte auch die Waffen mit grossen Ruhm»). Burkhard Mencke prosigue contando que, casado dos veces, Lope consiguió del papa licencia para entrar en la Orden de Malta. En su tierna infancia, cuando no sabía aún escribir, ya dictaba versos, y su fertilidad fue tan extraordinaria que logró completar 22 volúmenes de comedias impresas y más de mil manuscritos: «wie er denn in einem Abend eine Comödie hat schreiben können, imitierte auch in heroischen Gedichten den Ariosto, und schrieb La Belleza d'Angelica» y muchos otros poemas. 
grandes ganancias que obtuvo. A esto sigue un recuento de su obra, igualmente basado en la cantidad de textos que produjo el Fénix, que Dillon exagera notablemente. Sin embargo, el irlandés no se conforma con este panorama más bien cuantitativo y comenta también el estilo lopesco. Al respecto, sus observaciones se limitan al teatro del Fénix y siguen de cerca — como Velázquez- el prólogo cervantino a las Ocho comedias y el Arte nuevo, textos que Dillon cita en español. Sus ideas son de orden más bien clasicista y se centran en la obra dramática, pues el irlandés critica a Lope por abandonar el magisterio de los clásicos y las unidades de tiempo y lugar, amén del decoro. Pese a estas censuras, su impresión de la obra de Lope es más bien favorable, pues enfatiza siempre que el Fénix disponía de un estilo que hacía disculpables estos defectos, lo que no fue el caso en sus seguidores. Además, esta sección resulta interesante porque Dillon la emplea para criticar el teatro de su tiempo, en el que descubre manías y truculencias que percibe en Lope y, tal vez, en el propio Shakespeare. Finalmente, Dillon corona su semblanza con un panegírico del carácter del poeta, ponderando su buen corazón.

Además de por este fervor lopesco y por el clasicismo que también hemos señalado, el texto de Dillon destaca fundamentalmente por su tendencia a la hipérbole. Su fuente principal, la «Fama póstuma» de Pérez de Montalbán, ya era un panegírico, pero a ella Dillon añade una serie de detalles inventados que contribuyen a engrandecer la imagen del Fénix. Así, por ejemplo, el irlandés enfatiza mucho el éxito de Lope y el dinero que este le hizo ganar, lo que le lleva a calificar de «lucrativo puesto» el de protofiscal de la cámara apostólica y de «dama de elevada posición» a doña Juana de Guardo. En la misma línea, y movido por la simetría, hace que en sus honras oren tres predicadores (el dato lo trae Montalbán) y que oficien tres obispos (el detalle procede del entusiasta magín del irlandés). En cuanto a la numerosa obra del Fénix, Dillon la hincha con brío: donde Montalbán trae cincuenta libros impresos en total (comedias, poesías y prosas), el irlandés cuenta cincuenta de poesía y prosa, veintiséis de partes de comedias (el detalle es exacto) y, aparte, los autos sacramentales. A él le debemos la curiosa estimación de cuántos versos escribió Lope en vida, que según Dillon fueron 21.316.000.

\section{William Hayley, Esquire (1745-1820)}

En cuanto a William Hayley, fue un prolífico erudito, crítico, poeta y dramaturgo, recordado hoy sobre todo por su amistad con William Cowper, uno de los más conocidos poetas del último tercio del siglo XviII, de quien escribió una biografia (The Life and Posthumous Writings of William Cowper, 1803-1804), anterior a la más difundida de Southey. Con Southey compartía, de hecho, un gran interés por la literatura española, que en el caso de Hayley procede de la etapa como 
estudiante en Cambridge, cuando recibió clases de un profesor italiano, Isola, «intelligent and interesting man», dice en sus Memoirs, que tras iniciarle en el italiano y cuando ya lo leía y hablaba con fluidez, «continued to employ him in teaching them the language of Spain. They read with him several Spanish historians and poets» (Hayley 1823, I: 40-41).

Aquellas lecturas se observan en las varias referencias que Hayley hace a autores y títulos españoles tanto en sus ensayos y cartas como en sus dramas (algunas de sus obras sitúan la acción en España, pues confiesa tener «a predilection for Spanish characters» [1811: ix]). A través de su epistolario tenemos noticias precisas de su dedicación a los poetas españoles en los años 1781 y 1782. Así, por ejemplo, escribe a su esposa contándole que está muy enfrascado en la lectura detenida y cuidadosa de volúmenes españoles: «some Spanish volumes, lent me by no less a person tan his Excellency the Portuguese Minister» (Hayley 1823, I: 235). Otra de sus cartas, dictada el 20 de enero de 1782, se refiere con precisión a estos trabajos hispanistas: «I am at present translating passages from my favourite Spanish poet with great enthusiasm, as he delights me much, and I intend to give a very large representation of him in my notes, which will be very voluminous, and I fear still cost me several weeks close labour; but in the midst of my solitary employments I enjoy all your pleasures by reflection» (Hayley 1823, I: 260). Su esposa le responde seis días más tarde: «I rejoice in the pleasure which you derive from your favourite Spanish poet, and long for the time when I shall be amused with him also» (Hayley 1823, I: 262). El Essay salió ese mismo año.

Estos desvelos justifican que Hayley sea mencionado por Wiffen como uno de los primeros estudiosos de la literatura española en la lista que este hace de los principales hispanistas británicos; como hemos avanzado, en esta otra afición también adelantó a Southey, cuyo interés por la literatura española logró despertar, afirma Wiffen (1823: IX-X). Esa misma inclinación compartida lo vinculó también a Lord Holland, como afirma en sus Memoirs: «That amiable nobleman had honoured the poet of Sussex with a present of his Life of Lopez [sic] de Vega, accompanied by a very polite letter, declaring that he had been induced to learn the language of Spain by what Hayley had written of the heroic poet Ercilla» (Hayley 1823, II: 60). Holland debió de leer la Epistle on Poetry y remite en su Life and Writings of Lope de Vega a los juicios de Hayley sobre La Araucana, acompañados, dice con ponderación desmedida, por una traducción que mejora el original: «If that good-natured critic's judgment of the poem be somewhat too favourable, he gains over the English reader to it by the most agreeable of methods, the improvement of the Spanish author in his translation» (Holland 1806: 4). En cualquier caso, el interés de Hayley por los asuntos españoles le mantuvo en conexión con Holland y su grupo político hasta los años de la Guerra de la Independencia: en julio de 1808 Hayley comenzó «a new poem on a subject peculiarly 
interesting to his liberal mind. It was entitled The Stanzas of an English Friend to the Patriots of Spain. The author had it printed in London towards the end of the year, [...]. It was an anonymous publication» (Hayley 1823, II: 67).

Hayley conocía con toda seguridad las Letters de Dillon y probablemente también había tratado personalmente al viajero irlandés, a quien alude en sus epístolas como un «ingenious Traveller, who has lately published a pleasing volume of Letters on the Poetry of Spain». En cualquier caso, sabemos que leyó bien sus páginas sobre Lope, que también menciona y en las que el irlandés «has imputed the duel in which Lope de Vega was engaged to the gallantries of his first wife», asunto que veremos enseguida y sobre el que Hayley aduce otras fuentes, como Montalbán (Hayley 1782: 205). Como hemos avanzado, tal vez incluso tratara al propio Dillon, que pudo haber sido ese viajero al que también hace referencia en A Philosophical, Historical, and Moral Essay on Old Maids (Dublin 1785): «My friend, the learned traveller, writes me word from Spain, which he is now visiting on his return, that as soon as he reaches England, he shall correct for the press a journal of his tour» (Hayley 1793: 18).

Lo más interesante de An Essay on Epic Poetry: in Five Epistles... With notes son precisamente esas notas a las que se refiere el título y que ocupan dos terceras partes de la obra. De ella nos interesa ahora la epístola III, que Hayley dedica a los poetas del norte y de Provenza, amén de a «The most distinguished epic poets of Italy, Spain, Portugal, France and England», aquí encontramos los 22 versos que dedica a Ercilla y su Araucana (1782: 43-67), que el inglés acompaña y enriquece con 66 páginas de notas eruditas y comentarios, incluyendo traducciones y resúmenes de diversos pasajes. Este interés por Ercilla era común en la Inglaterra de la época, donde los hombres de letras consideraban La Araucana una de las grandes obras épicas de todos los tiempos. Puede observarse, por ejemplo, en la obra de Richard Twiss, Travels through Portugal and Spain, in 1772-1773 (1775), que se expresa largamente contra la opinión negativa de Voltaire acerca del poema épico español y dedica varias páginas a presentarlo muy elogiosamente, reproduciendo varios fragmentos (Twiss 1775: 386-397). Es más, Ercilla y su Araucana habían sido ya motivo de polémica y debate entre los defensores de la poética neoclásica, como Voltaire, y los que defendían sus valores: el primero, Dieze, en su traducción de los Orígenes de Velázquez, luego, López de Sedano y, desde Italia, los jesuitas Lampillas y Juan Andrés. De ellos, Dieze y Hayley adelantan la revalorización de Ercilla que llegará sobre todo con Bouterwek y los Schlegel (Pierce 1982: 232).

Entre las notas con las que Hayley ilustra su epístola sobre Ercilla llama la atención la número IX, dedicada a Lope de Vega, «perhaps the most fertile poet in the annals of Parnassus», del que traza una larga reseña biográfica acompañada de ciertos comentarios sobre su obra (1782: 202-207). En ellos se observa, como en general en el resto del libro, una posición estética en la que están operándose 
cambios importantes y se debaten conceptos sustanciales que dejan ver la transición desde la poética neoclásica a la propia de fines de siglo. Una de estas posturas, por ejemplo, es la preferencia por la idea de genio frente a las reglas. Estas están representadas por lo que Hayley llama el «systematical criticism», encarnado en Voltaire (Hayley 1782: 296), ideología que en las notas a la epístola quinta afirma combatir calurosamente, reivindicando un arte «which his genius and learning have cast many rays of pleasing and useful light» (1782: 297), esto es: desde el genio y la luz del placer (sin olvidar la utilidad). Aunque su posición coincide en general con los criterios ilustrados - como el buen gusto-, su acendrado sentimentalismo, su melancolía sensible y el placer que muestra en los extremos de terror y piedad están ya en parte adelantando nuevos valores.

Asimismo, en la citada nota al An Essay on Epic Poetry, Lope aparece en otras obras anteriores de Hayley: en An Essay on History: in Three Epistles to Edward Gibbon (1780) el inglés hace varias referencias a autores españoles, particularmente en las notas a la epístola III. Junto a las consabidas críticas a Felipe II, reconoce con Antonio de Herrera, «a Spanish Historian of great reputation» (del que dice usar su Historia General del Mundo de 1612), que «his reign may be considered as the Augustan age of Spanish literature. His most bloody minister, the merciless Alba, was the Maecenas of that wonderful and voluminous Poet, Lope de Vega» (Hayley 1780: 155) ${ }^{19}$. Y en An Essay on Painting, in a Poetical Epistle to an Eminent Painter (1781) se refiere al discípulo de Tiziano, Juan Fernández Ximénez de Navarrete, para cuya presentación «I have ventured to borrow something like a conceit from the famous spanish Poet Lope de Vega, who has celebrated his talent in the following verses», y copia el poema «Del Mudo, pintor famosísimo» («No quiso el cielo que hablase») (nota XXIII al verso 305) (Hayley 1781: 73). Añade después que ha tomado su breve presentación del poeta de las Vidas de los pintores españoles de José de Palomino Velasco, muy difundida, naturalmente, en Inglaterra (London, 1744).

Sin embargo, más que en estas menciones de pasada vamos a centrarnos en la semblanza lopesca de Hayley, que aparece en la citada epístola III de su Essay on Epic Poetry, en una nota motivada por una mención al Fénix en el texto. Pese a la diferencia genérica inicial que separa a los dos libros, la estructura de la biografía de Hayley difiere poco de la de Dillon, a la que parece seguir a la hora de resumir la «Fama póstuma» de Montalbán. Así, Hayley narra en primer lugar la infancia y juventud del poeta, enfatizando como Dillon la nobleza de sus padres (añade la noticia acerca del nombre de la madre de Lope, procedente de Montalbán) y las

19 Hayley confunde aquí a don Antonio, quinto duque de Alba y mecenas de Lope, con don Fernando, el Gran Duque de Alba y gobernador de Flandes. El error estaba extendido en el lopismo inglés del momento (Shelley 2015: 121). 
tempranas muestras de ingenio del escritor. Evidentemente, la fuente de esta sección - y de toda la semblanza - es Montalbán, con el que Hayley completa cuidadosamente el resumen de Dillon. Así, por ejemplo, Hayley añade el detalle de la escapada de Lope y un joven amigo a Astorga, a la que Montalbán dedica considerable atención pero que Dillon elimina de su texto. A continuación, Hayley narra la formación del poeta (su estancia con don Jerónimo Manrique y su etapa en la Universidad de Alcalá) y sus «Wanderjahre»: el matrimonio con Isabel de Urbina, el duelo y exilio a Valencia, el regreso, la muerte de Isabel y la participación en la Armada. A diferencia de Dillon, Hayley explica el duelo acudiendo a las complejas razones de Montalbán, aunque añade que un viajero inglés (Dillon) ha relacionado el episodio con el cortejo de Isabel de Urbina, extremo que niega Hayley aduciendo como prueba el intercambio de epístolas poéticas entre Lope y Medinilla. Luego, Hayley pasa a tratar la madurez del poeta, que cuenta como Dillon y siguiéndole en algunos extremos (la nobleza de Juana de Guardo), aunque añade el detalle de los hijos de Lope y la muerte de Lopito (que no aparece mencionado por su nombre). También sigue a Dillon y a Montalbán en los pasajes dedicados a la muerte y exequias del Fénix, aunque corrigiendo los errores y exageraciones del viajero irlandés. Del mismo modo, se inspira en Dillon al hablar de la fama del autor y de su obra, sobre la que adopta el detalle de los 21 millones de versos, debido al irlandés. Por tanto, la contribución más original de Hayley no debe buscarse en esta biografía, sino en la sección que dedica al análisis de la obra de Lope, que el autor inglés centra en las epopeyas del Fénix, las que le interesan para su Essay on Epic Poetry. Concretamente, Hayley comenta La Dragontea, La hermosura de Angélica y la Jerusalén conquistada, obra que compara desfavorablemente con la Gerusalemme de Tasso y con la magnum opus de Ercilla. Asimismo, el inglés explica brevemente el Laurel de Apolo, que ya había usado para hablar del padre de Lope, y las Rimas. Concretamente, Hayley trae a colación el soneto a la Armada, que le sirve para cerrar su comentario al comparar su grandilocuencia con la del inicio del panegírico de Montalbán. Por último, dedica unos versos y una nota aparte a las riquezas que amasó Lope y a la generosidad del Fénix, extremos que llevan al inglés a una digresión acerca de la necesidad de financiar los esfuerzos de los hombres de letras.

\section{Dillon y Hayley en su entorno europeo}

En conclusión, las semblanzas lopescas de Dillon y Hayley son textos pioneros en el lopismo inglés, previos a los estudios de Lord Holland (Some Account, de 1806) y Shelley (Cervantes y Lope, de 1837), mucho más conocidos e influyentes, y ya decimonónicos. Comparadas con ellos, las semblanzas dieciochescas no se 
rinden sin más a las incipientes ideas románticas, pero sí las anuncian, situándose en una línea que amplía la visión de los Orígenes de Velázquez y que entronca con la tradición de Lessing, Dieze y los jesuitas expulsos, y que acabará siendo claramente reivindicativa en Herder. Así, si bien Dillon y Hayley están lejos aún de los valores propiamente románticos, sí corresponden a ese «despliegue del teatro lopesco» que contribuyó a flexibilizar el paradigma poético post-aristotélico en el último periodo ilustrado previo a la revolución romántica; y lo hicieron en el marco de ese «diálogo comparatista que ponía en relación textos de diversas tradiciones lingüísticas y culturales» (Romero Tobar 2010: 463), contexto en el que deben leerse sus páginas. Y es que, por una parte, tanto Dillon como Hayley delatan una formación clasicista que se revela en sus críticas a la comedia nueva, que censuran por alejarse de los preceptos clásicos. Sin embargo, por otra, este clasicismo moderado no les impide admirar las creaciones del Shakespeare español, Lope, creaciones que les resultan impresionantes por su estilo genial en medio de lo que perciben como errores formales propios de una imaginación excesiva y desviada. Además, y en contraste con el hispanismo de corte schlegeliano, estos autores no usan el modelo de la literatura del Siglo de Oro para proponer una literatura alternativa a la del clasicismo francés, y no exaltan la dramaturgia de Calderón, aunque la primera propuesta - Lope como alternativa al clasicismo francés- está implícita si leemos los textos de Dillon y Hayley en el contexto de la poética europea del momento.

Y es que, insistimos, las obras de los dos escritores británicos se escriben en el contexto de un intenso debate que pone en cuestión el fuerte dominio del modelo literario francés en el panorama europeo. Precisamente en esta época se comenzó a usar la literatura española como contramodelo de la francesa: como nuestras letras habían sido denigradas por el célebre artículo de Masson («Espagne») en la Encyclopédie, se generó entre los partidarios de las dos tradiciones literarias una polémica que en realidad servía para poner en entredicho la autoridad de los galos, a los que, al defender a España, atacaban tanto los alemanes como los españoles y algunos italianos. Esto es: en términos polisistémicos, podríamos sostener que estamos en el marco de una confabulación de la periferia contra el centralismo canónico francés o, como piensa Cabo Aseguinolaza (2003: 16-18), de una reordenación geocultural en el panorama europeo. Aunque los británicos asisten al debate sobre España con algo de distancia, no dejan de aprovechar la ocasión para aliarse con las tendencias renovadoras y arremeter contra Francia. De hecho, los modelos dramáticos ingleses y en especial Shakespeare sirvieron junto a Lope para demostrar, a través de criterios como la genialidad, la fertilidad o la imaginación, la fuerza de unas obras que no se sometieron a las reglas. En suma, estamos ante una polémica de gran trabazón internacional en la que las tesis surgidas en territorio germano nutrieron y reforzaron otras que se difundían 
en Inglaterra, o viceversa, en la que los estudiosos alemanes se alimentaron de textos ingleses. Concretamente, para el caso de Lope es fundamental apuntar el papel de Lessing y Herder (sin ignorar sus precedentes inmediatos: Johann Friedrich Von Cronegk y Christian Schmid) y su influencia en algunos juicios de los autores británicos ${ }^{20}$.

En cuanto a Lessing, su obra pudo ir preparando el interés de Dillon y Hayley por Lope, puesto que el alemán - traducido y difundido pronto por toda Europa- adelanta alguno de los argumentos que después se convertirán en puntales de su defensa, como el usar la naturaleza como modelo, pues «no puede ser un defecto nada que sea imitación de la naturaleza» (Lessing 1993: 389) ${ }^{21}$. La búsqueda alemana de un teatro nacional lleva a Lessing a proponer, frente al modelo francés, una nueva estética apoyada en Shakespeare y Lope, siguiendo el concepto de genio, lo que sirvió para dar «un fuerte impulso a la recepción del teatro español, hasta entonces desconocido en Alemania» (Rivero Iglesias 2010: 845856). En cualquier caso, sus ideas fueron muy influyentes, pues desde la Hanburgische Dramaturgie (1769) es habitual usar la comparación entre Lope de Vega y Shakespeare como argumento contra la rigidez del clasicismo. Prueba del éxito de esta concepción es el ejemplo de Herder, que recurrió asimismo a la analogía entre el Fénix y el Bardo.

También es muy probable que Dillon y Hayley conocieran las muy difundidas opiniones del propio Herder. Como sabemos, el alemán era muy aficionado a Lope, al que curiosamente prefirió a Calderón, a pesar de que La vida es sueño ya había sido traducida y comentada entre los hispanistas germanos, y de que se convertirá en el título de referencia de la renovación romántica y motivo de la preferencia schlegeliana - y de toda la escuela hispanista alemana - por este autor frente al

20 Cronegk ya había apuntado en 1761 cómo los autores del Siglo de Oro (desconocidos en la Alemania de su tiempo) habían sido los modelos de los franceses entonces en boga (1761:387). También Christian Schmid insiste en ese préstamo (1767: 70-72). Ambos promueven el estudio del teatro español, como Lessing después, sobre todo por su originalidad frente al rigor de la normativa dramática francesa.

21 Sobre la presencia de Lope en la obra de Lessing y el alcance de sus conocimientos e influencia, ver Spang (2010) y González García (1997), quien no comparte los juicios de Pitollet y Wellek acerca de los escasos conocimientos de Lessing sobre la lengua y literatura española. Lessing tuvo una fase (años 1767-1770) en la que sintió a Lope de Vega como unos de sus maestros en la comprensión de la naturaleza humana y se orienta en el Arte nuevo para tratar en su Dramaturgia sobre la teoría de los tres actos, la combinación de situaciones y caracteres o la mezcla de lo trágico y lo cómico. Spang señala que «Lessing conoció y leyó a Lope, ya que menciona y comenta expresamente su Arte nuevo y sus comedias en varias anotaciones de su Dramaturgia (LXIX, LXX). Sin embargo, ello no significa que Lessing haya sido admirador del autor español». Aunque «ambos coinciden en que la naturaleza es la mejor maestra y la guía soberana del dramaturgo», difieren en la relación entre lo cómico y lo trágico (Spang 2010: 258 y 261-262). 
Fénix (Farinelli 1936) ${ }^{22}$. Aunque los conocimientos de Herder sobre el drama español del Siglo de Oro fueron más bien escasos (según Vega 1997: 159-160), y en algunas ocasiones copiados literalmente de Daniel Schiebeler (Kayser 1945: 68), le sirvieron para generar una imagen de Lope que privilegia la relación del vate madrileño con el pueblo y con las raíces del carácter nacional, expresado genialmente en su obra. Esta mezcla de genio y expresión directa de la naturaleza del pueblo del que procede es la que permite a Herder usar al dramaturgo español, junto a Shakespeare, como argumento contra Klotz para enfrentar las reglas del clasicismo francés en sus Kritische Wälder de 1769 (Herder 2014: 214-215) ${ }^{23}$. Como bien ha visto Joan Oleza (1996), los criterios de Herder fueron los que se mantuvieron desde el Sturm und Drang hasta el romanticismo del conde Schack para preferir a Lope sobre Calderón, en divergencia con los Schlegel. Schack apela sobre todo al genio del autor, desautorizando al Lope teórico, al que, piensa, no debe tomarse en serio porque no tiene suficientes conocimientos como para argumentar su propio arte.

La influencia de esta reivindicación alemana en Dillon puede suponerse, ya que el autor irlandés sabía alemán y había vivido en Austria durante los años de mayor difusión de las ideas de Lessing y Herder (el mismo Mayans se asombra en una carta de la erudición de Dillon, reconociendo sus habilidades para el alemán, italiano, francés y portugués, además del español, según recoge Marino [2014: 194]). También es probable que conociera la traducción alemana de su fuente fundamental, los Orígenes de la poesía castellana de Velázquez, traducción que - con larguísimos y fundamentales comentarios y notas - hizo Dieze en 1769 y que usará, por ejemplo, el también inglés Henry Hallam (1837). En la versión de Dieze son frecuentes las notas sobre Lope de Vega en las que se amplían los juicios de Lessing, proponiendo al dramaturgo español como modelo de los nuevos

22 Para Farinelli la fama germana de Lope en Alemania no llegó nunca a la popularidad alcanzada en el ámbito inglés o incluso francés a causa del Curso de literatura dramática de August W. Schlegel, cuya última entrega de 1808 presenta al Fénix como improvisador semibárbaro, frente a Calderón, convertido en el gran dramaturgo español. También por eso tuvo menos traductores e imitadores (Malsburg y Zedlitz entre ellos). Sigue siendo válido el repaso de Hermann Tiemann (1939). Oleza (1996) señala que «Lope fue el precio que Friedrich Schlegel, con su severa crítica, hizo pagar al teatro español para poder entronizar a Calderón en el parnaso romántico europeo. Entregó voluntariamente a un Lope que no había leído a las zarpas de la crítica neoclasicista a cambio de rescatar para la romántica a Calderón. La operación de Friedrich, secundada y exportada por su hermano August Wilhelm, tuvo un casi completo éxito».

23 En el primer apartado, tratando de las cartas homéricas defiende a Lope de Vega de las críticas de Klotz («Rettung des Lope di Vega und Milton, in Absicht auf ihre Lachsucht»), y lo incluye entre los grandes genios de todos los tiempos y pueblos, como debelador de todas las reglas y artífice de todas las conjunciones entre verdad y fábula, comedia y tragedia, comicidad y seriedad, ante quien Klotz solo puede inclinarse temeroso, más aun porque el propio Lope supo defenderse, explicar sus propios criterios y opiniones (Herder 2014: 37). 
valores de originalidad y genialidad. Precisamente Mayans, a quien, como hemos visto, visitó Dillon en su viaje español, fue uno de los apoyos eruditos del círculo de hispanistas de la Universidad de Göttingen, en cuya biblioteca se nutrió Dieze para preparar esa traducción anotada de los Orígenes (poseía los tres volúmenes de las obras de Lope, según refiere Eck [1997: 109]). A su vez, el valenciano, en su correspondencia con Klopstock, había ya difundido sus ideas sobre Lope de Vega: su desprecio por las reglas del arte, pero también su extraordinario ingenio, que le convirtió - según Mayans escribe al alemán — en el más grande de los comediógrafos (Mestre 1997: 83). La conexión entre Mayans, Dieze y Dillon hace esperable que los tres ingenios compartieran este mismo juicio, así como también la visión cervantina (recuérdese el cervantismo de Mayans) sobre el Fénix, visible perfectamente tanto en Dieze como en Dillon, que la recibe directamente de su principal fuente, los Orígenes de Velázquez. Recordemos que ahí Velázquez sigue muy de cerca las críticas cervantinas sobre Lope: la falta de decoro en los personajes (por su abundancia y lenguaje), la ausencia de unidad de tiempo, la inverosimilitud y el interés en complacer al vulgo (Velázquez 1754: 107-108). Sin embargo, Velázquez le concede al Fénix una «prodigiosa fecundidad», que también se apoya en referencia cervantina («como dice Cervantes, escribió más de diez mil pliegos de comedias»), y pondera «su nunca vista facilidad», con la que alucinó «a los que no están obligados a saber distinguir en estas materias los verdaderos partos del ingenio de los abortos del antojo y del capricho». La culpa mayor de Lope se demuestra en el Arte (como había dicho Lessing en las mismas fechas y era ya asunto de debate), pues a pesar de conocer las reglas y «con pleno conocimiento de lo mal que hacía en pervertir las buenas reglas del teatro, quiso sacrificar a su propio interés el de las letras» (Velázquez 1754: 109-110) ${ }^{24}$. La evidente similitud entre los juicios de Mayans sobre Lope (Mestre 1997: 83), los de Velázquez, Dieze y Dillon, remiten a esa común fuente cervantina que todos secundan, aunque también incorporando o matizando opiniones. Por consiguiente, las ideas de Dillon y Hayley resultan mucho más llamativas de lo que podrían parecer inicialmente si tenemos en cuenta el contexto del debate europeo sobre el clasicismo, y la conexión que lleva desde Velázquez hasta Dillon, pasando por Mayans y Herder ${ }^{25}$.

24 Velázquez remite también a la opinión de Luzán sobre Lope y Calderón, que observa en ellos, según cita textualmente: «rara ingeniosidad, singular agudeza y discreción, prendas muy esenciales para formar grandes poetas y dignas de admiración; y añado que en particular alabaré siempre en Lope de Vega la natural facilidad de su estilo y la suma destreza con que en muchas de sus comedias se ven pintadas las costumbres y el carácter de algunas personas» (Velázquez 1754: 115; cfr. Luzán Poética 3, 15).

25 Una prueba del asomo en los textos que nos ocupan de las ideas contrarias a un clasicismo rígido la encontramos si examinamos, en el texto de Dillon, la importancia del concepto de genio, aplicado a Lope. Aparece claramente en el texto del irlandés (no así en Hayley, que no entra 


\section{CONCLUSIÓN}

Un elemento que Dillon y Hayley tienen en común con esta tradición y con los lopistas decimonónicos es el enorme aprecio que sienten por la figura del Fénix. Ambos le dedican la máxima alabanza posible en labios ingleses - Lope es para ellos nada menos que el Shakespeare español- y ambos le sitúan muy por encima de Quevedo, Calderón o Góngora, en el Parnaso de las letras hispanas. Como hemos visto arriba, esta apreciación no es acrítica. Dillon y Hayley son típicos de la Inglaterra de su época en su gran amor por Cervantes y juzgan el teatro de Lope a través de los célebres comentarios cervantinos del prólogo a las Ocho comedias y la primera parte del Quijote — vemos aquí, de nuevo, la huella de Velázquez y Mayans-, lo que resulta desfavorable para el Fénix. Además, Hayley no duda en criticar la Jerusalén lopesca, que le parece inferior a la de Tasso - sin duda por la libertad ariostesca de la obra del Fénix - y a la Araucana de Ercilla. Pese a ello, ambos autores celebran al poeta madrileño, fijándose en su increíble producción (el dato de los 21 millones de versos, acuñado por Dillon, aparece en ambos autores) y en su admirable carácter, que les parece modélico. Recordemos que estamos todavía en una etapa del lopismo previa a la aparición del epistolario y del proceso por libelos, y en la que, por tanto, el panegírico de Pérez de Montalbán es la fuente principal sobre la personalidad y costumbres de Lope.

En otro orden de cosas, resaltemos que en los textos de nuestros hispanistas se perciben mensajes particulares dirigidos al mundo literario de su época. Así, Dillon comenta los supuestos excesos de las comedias lopescas (truculencia de los finales, número excesivo de actores) para fustigar el teatro del momento, rechazando ya la posible influencia de la estética gótica, ya ciertas obras shakespereanas. En cuanto a Hayley, enfatiza los honores y riquezas que Lope recibió en vida para contrastarlos con la parquedad de las autoridades británicas para con los autores locales, con lo que difunde un mensaje muy lopesco acerca de la necesidad de financiar adecuadamente a los escritores del momento.

a valorar la obra teatral del Fénix, que es la conflictiva y en relación con la que se habla de la genialidad del dramaturgo), lo que no deja de ser interesante porque de esta idea saldrá la posterior reivindicación de Lope, convertido en protagonista del nuevo modelo de autor instintivo y popular (que ya elogiaba Herder). Dillon está escribiendo antes de que se publique y difunda en Inglaterra - de mano de Coleridge - la teoría kantiana de la genialidad, pero toda la discusión sobre el genio tiene una anterior trayectoria inglesa que evidentemente conocía: el concepto — con origen en Edward Young (Conjectures on Original Composition, 1759), que ya convierte a Shakespeare en prototipo de una manera «original» de imitación- aparece en William Duff (Essay on Original Genius, 1767), Robert Woods, Essay on the Original Genius and Writings of Homer (1769) y Alexander Gerard, Essay on Genius (1774) (Bruno 2010: 13). En la segunda mitad del XVIII, el término inglés «genius» se refería a un atributo asociado a la fuerza intuitiva e imaginativa (Bate 1997: 136; Bruno 2010: 12; Class 2012: 161) y estuvo asociado a otro concepto de importante recorrido histórico: el «wit», que usa Hayley para referirse al ingenio pronto de Lope. 
En cuanto a las fuentes manejadas, ambos autores muestran conocer las Obras sueltas, que es donde han encontrado la biografía de Montalbán de donde obtienen la mayor parte de su material, así como el Arte nuevo y la epístola A Claudio, que citan. Sin embargo, Dillon y Hayley no son en absoluto comparables en cuanto a su conocimiento del corpus lopesco. Incluso en lo referente a la «Fama póstuma» Hayley nos proporciona una información mucho más completa, en una tendencia que se confirma al observar qué otras obras mencionan con cierta profundidad: Dillon le debe mucho a Velázquez, y de Lope parece haber leído el Arte nuevo, la epístola $A$ Claudio y alguna que otra comedia; Hayley, esas obras, las Rimas (al menos el soneto a la Armada y la descripción de la Abadía del Duque de Alba), el Laurel de Apolo y las tres epopeyas que comenta en detalle: La Dragontea, La hermosura de Angélica y la Jerusalén conquistada. Además, demuestra haber hojeado varios volúmenes de las Obras sueltas, pues sabe que Lope le dedicó diversas obras al duque de Alba y conoce las epístolas que se cruzan Medinilla y Lope sobre Isabel de Urbina. Sin embargo, no da muestras de haber leído otras epopeyas lopescas que habrían completado sus ideas acerca del arte épico del Fénix: nos referimos al Isidro y la Corona trágica, que Hayley no contempla en su estudio.

Por último, destaquemos que Dillon y Hayley no adolecen del rancio antiespañolismo que persiste en muchos hispanistas decimonónicos. Así, pasan por encima del hecho de que Lope fue familiar de la Inquisición sin criticarlo y no dejan ver, en general, sus prejuicios religiosos ${ }^{26}$ (Dillon, curiosamente católico, sí que fustiga la religiosidad española en sus Travels). Además, solo Hayley comenta el desastre de la Armada y el hecho de que La Dragontea se dirija contra Isabel I y Drake, pero sin la fruición de otros autores decimonónicos. Tampoco critican el modo de escribir español en general, como sí hace, por ejemplo, Shelley (2015): Hayley sí que habla de la fanfarronería española al tratar el soneto de la Armada y el comienzo del panegírico de Montalbán, pero no al tratar el resto de la obra de Lope o la de otros autores españoles que comenta, como Ercilla. Son solo algunos de los muchos elementos de interés que se destilan de la lectura de las semblanzas de estos pioneros del lopismo moderno en Inglaterra.

26 Aunque la leyenda negra tenía para entonces una larga trayectoria y las alusiones a la superstición y fanatismo de los españoles son frecuentes en los comentarios de otros viajeros ingleses (Bacigalupo 1978: 122-123, 133-134), fue con los movimientos políticos liberales contra Fernando VII, en los que estuvieron involucrados los británicos, cuando se convierte en lugar común acusar a la intolerancia religiosa de todos los males de España. La vuelta de Fernando VII no favorecía a los intereses económicos de Inglaterra; una de las mejores maneras de criticarlo era recordar los crímenes del Tribunal de la Inquisición, que él restauraría. 


\section{APÉNDICE}

En las páginas que siguen ofrecemos una traducción de las biografías de Lope de Dillon y Hayley. La de Dillon es su «Sketch of the Life and Character of the Famous Poet Lope de Vega», la XV carta de su obra, escrita en Madrid, el 15 de agosto de 1778 (Dillon 1781: 249-262).

En cuanto a la de Hayley, se trata de la nota IX al verso 209 de la tercera epístola de su An Essay on Epic Poetry (1782: 202-207), en que el autor proporciona a los lectores una biografía de Lope y una evaluación de su obra centrada, como cabría esperar, en la poesía épica del Fénix, y en particular en la Jerusalén conquistada. Además, tratan de Lope unos versos de la epístola cuarta (1782: 85-86, vv. 301-318) y su comentario (1782: 291-292), que también traducimos.

Modernizamos la ortografía y puntuación, y corregimos erratas y deturpaciones de nombres propios («Juana de Guardia», «Juana de Guardio», «Barbarini») sin más aviso. Recurrimos a los versos originales de Lope cuando los autores dieciochescos los traducen, y al texto de Montalbán cuando lo citan en español.

\section{Dillon: CARTAS DE UN VIAJERO INGLÉS a ESPAÑa (pp. 249-262)}

Esbozo de la vida y carácter del famoso poeta Lope de Vega.

Madrid, 15 de agosto de 1778

Aunque comparto totalmente tu opinión acerca de nuestro inmortal Shakespeare, no puedo evitar hacerle a su contemporáneo Lope de Vega la justicia que merece su extraordinario talento. Por tanto, trataré de ofrecerte un esbozo de este gran poeta, tarea nada fácil si consideramos sus increíbles dotes. Sin embargo, intentaré hacerlo, pues esta será la última carta que te escriba desde aquí.

Lope Félix de Vega Carpio, nacido el 25 de noviembre de 1562, fue hijo de Félix de Vega Carpio, un caballero de Madrid que tenía reputación de buen poeta, don que también observó encantado en su hijo desde su infancia y que el cariñoso padre fomentó con el mayor deleite. A la edad de cinco años Lope sabía leer de corrido en español y latín, e incluso hacía versos, que les trocaba a sus compañeros por dibujos y otras niñerías. Su padre, encantado con esta sorprendente muestra de genio, no reparó en esfuerzos para cultivar una planta que parecía alimentar las más brillantes expectativas. A los doce años, Lope dominaba el latín y el arte retórica, sabía bailar y esgrimir con facilidad y destreza, y cantar aceptablemente. 
Ya adornado de estas habilidades, quedó huérfano cuando apenas entraba en el mundo y sus tribulaciones, y fue acogido al servicio del obispo de Ávila, en cuya alabanza escribió varias églogas y su primer intento dramático, la comedia titulada La pastoral de Jacinto. Poco después dejó el servicio de este mecenas y acudió a la Universidad de Alcalá, donde estudió filosofía y se graduó, regresando luego a Madrid para ser secretario del duque de Alba, quien le confió sus asuntos más delicados. Animado por su nuevo mecenas, retomó la lira y cantó sus alabanzas en un poema titulado Arcadia. Por esta época se casó con doña Isabel de Urbina, una dama elegante a causa de cuyo cortejo tuvo poco después que batirse en duelo. En este hirió de gravedad a su rival, por lo que huyó a Valencia, donde vivió durante varios años.

Después regresó a Madrid, donde, habiendo muerto su mujer, se vio inflamado de ardor guerrero y se dirigió a Cádiz para embarcarse en la gran Armada que Felipe II disponía contra la reina Isabel. A bordo de esta flota se dirigió a Lisboa en compañía de su hermano, teniente en la marina española que perdió la vida en la expedición. Nuestro poeta también sufrió en la desafortunada expedición y regresó a Madrid sin un solo amigo.

Allí se hizo secretario del marqués de Malpica y luego del conde de Lemos. Aunque su primer matrimonio fue tan poco afortunado, esperaba tener más suerte en ese estado junto a Juana de Guardo, una dama de elevada posición a la que perdió poco después. Inconsolable por estas constantes desgracias, se hizo eclesiástico, fue ordenado sacerdote y nombrado capellán de una congregación de sacerdotes de Madrid, aunque todavía cultivaba las musas en lo que era la principal distracción de sus penas.

Estaba entonces en el cénit de su gloria poética y su reputación se hizo tan universal que el papa Urbano VIII le envió el título de doctor en teología y la cruz de la orden de Malta, a lo que añadió un lucrativo puesto en la contaduría apostólica que Lope ostentó hasta su muerte.

Esta le sobrevino a los setenta y tres años de edad, para gran tristeza de la corte y de todos los sabios del reino. El duque de Sessa, que era su mecenas y albacea, le enterró a sus expensas con una pompa y magnificencia que nunca se había visto para una persona privada. Invitó a todos los grandes del reino, que asistieron en persona para mostrar su consternación por la pérdida de un hombre tan distinguido. Las exequias se prolongaron durante tres días: asistieron todos los clérigos de la capilla real, oficiaron tres obispos y tres de los más elocuentes oradores se esforzaron para alabar al difunto, añadiendo nuevos laureles a la fama de Lope de Vega, a quien, cuando vivía, muchos príncipes se gloriaban de haber tratado.

El papa Urbano le escribió una carta agradeciéndole la dedicatoria de su poema a favor de María, reina de Escocia, titulado Corona trágica de María Estuarda. El cardenal Barberini mantuvo correspondencia personal con él, como 
hicieron muchos otros cardenales y nobles que buscaron su amistad. Cuando iba por la calle le señalaban como un prodigio y, además, le cargaban de regalos. Al vender sus obras amasó una fortuna considerable y adquirió un capital de 150.000 ducados, amén de unos ingresos anuales de 15.000 ducados procedentes de sus beneficios eclesiásticos y empleos.

Tanta fue la fertilidad de su genio, la impresionante destreza de su mente y la rapidez de su pensamiento, añadidos a su animada expresión, que quizás no haya habido nunca poeta en el mundo, antiguo o moderno, que pueda comparársele. Sus composiciones líricas y poemas de ocasión, con sus ensayos en prosa, forman una colección de cincuenta volúmenes, a los que hay que añadir sus obras dramáticas, que suman veintiséis volúmenes más, quitando las cuatrocientas obras dramáticas sobre las Sagradas Escrituras, llamadas en español «autos sacramentales», todos representados con éxito. Y, lo que es más extraordinario, hablando de sus obras impresas en una de sus églogas, la titulada $A$ Claudio, dice que forman una mínima parte de lo que le queda inédito. Parece, según afirma él mismo, que solía escribir cinco pliegos al día. Multiplicados por los días de su vida esto se eleva a 133.224 pliegos, lo que, calculando el número de versos que corresponde a cada pliego, significa que, quitando la prosa, habría escrito 21.316 .000 versos, lo nunca visto de esfuerzo y facilidad de versificación. Nuestro autor poseía una vena inextinguible que, como el fuego del Vesubio, le proporcionaba nuevos materiales constantemente y ardía sin cesar. Tan extraordinaria era la rapidez de su genio que a menudo acababa una obra en veinticuatro horas y algunas comedias en menos de cinco, con tanta corrección y elegancia en los versos como ostentaban las más trabajadas obras de los otros ingenios del momento. Así fue el contemporáneo de Sir Philip Sidney, Shakespeare y Spenser.

En su Laurel de Apolo alaba a todos los buenos poetas de su tiempo, pero ninguno fue tan universalmente admirado como él. Su increíble talento era tal que en su obra dramática rompió las reglas del arte, pero con tal éxito que fue constantemente el favorito del público y recibió el perpetuo aplauso de sus conciudadanos. No fue culpa suya que sus seguidores no tuvieran su talento para esconder sus defectos e imitaran solo sus imperfecciones, haciendo el teatro español insoportable cuando le quitan las bellezas del estilo de Lope. Esto lo predijo Cervantes, quien le reprocha a nuestro poeta haber destruido las reglas del teatro tal y como las fijaron los antiguos, y todo para procurarse el aplauso popular, en aras del cual se alejó de toda noción de naturaleza o buen gusto, a lo que hay que añadir que la verosimilitud de las tramas languidecía en sus manos a la sombra de la encantadora magia de sus versos. Además, aniquilaba toda unidad de tiempo y lugar: sus héroes salían de la cuna y recorrían el oriente u occidente en sus amores o batallas, vestían hábito de monje, morían en los claustros o hacían milagros en las tablas. El escenario pasa de Italia a Flandes y se traslada con facilidad de Valencia a 
México. Los criados hablan como cortesanos, los príncipes, como matones, y las damas, como sirvientas. Los actores son legión, a menudo setenta a la vez, y rematan la obra con numerosas procesiones, lo que todavía se estila entre nosotros. Además, solían concluir las comedias abriendo tumbas y enterrando muertos, u oficiando los más horribles ritos funerarios para divertir al público. Por mi parte, confieso que mi corazón se estremece al ver tales cosas y que ni el más cautivador discurso de Shakespeare me hace superar esta impresión ante tamaña falta de decoro.

Tan sensible era Lope a su salvaje imaginación y tanto jugó con la confianza del público que, hablando de sí mismo, reconoce su error con las siguientes palabras:

Mas ninguno de todos llamar puedo más bárbaro que yo, pues contra el arte me atrevo a dar preceptos, y me dejo llevar de la vulgar corriente a donde me llaman ignorante Italia y Francia ${ }^{27}$.

Y, de nuevo:

Y escribo por el arte que inventaron los que el vulgar aplauso pretendieron, porque, como los paga el vulgo, es justo hablarle en necio para darle gusto.

Esto es, admite que era consciente de los reproches que le harían en Italia y Francia por haber roto todas las reglas para complacer al vulgo ignorante, pero argumenta que, como eran ellos los que pagaban, consideraba que tenían derecho a que se les complaciera a su modo.

Te he ofrecido aquí los dos lados de la argumentación, respetando a este gran hombre. Si te tuviera que hablar de sus virtudes personales, son incluso superiores a su talento literario. Su benevolencia y caridad hacia los indigentes y desgraciados era tal que siempre le tendía su mano al que lo necesitaba, de modo que, pese a su considerable fortuna e ingresos, a su muerte se le hallaron no más de 6.000 ducados. ¡Oh, bardo ilustre, si un inglés no puede hacer justicia a tus ritmos poéticos y a la armonía de tus versos, acepta al menos este tributo a la bondad de tu corazón!

27 [N.T. $]$ En español en el original, tanto en este caso como en el siguiente. Como cabría esperar, Dillon toma el texto de la reciente edición de las Obras sueltas. 


\section{HaYley: UN ENSAYO SOBRE POESÍA ÉPICA (pp. 202-207)}

Y juzga imprudente que la lira de su Vega. El famoso Lope de Vega, frecuentemente llamado «el Shakespeare de España», es tal vez el poeta más fértil en los anales del Parnaso y sería difícil nombrar un autor, antiguo o moderno, tan universalmente adorado en vida entre todas las clases sociales y tan magníficamente recompensado por la liberalidad de los poderosos. Fue hijo de Félix de Vega y Francisca Fernández, ambos descendientes de honradas familias y habitantes de Madrid. Nuestro poeta nació en esa ciudad el 25 de noviembre de 1562. Fue, según su propia expresión, poeta desde la cuna y, como empezó a hacer versos antes de saber escribir, les ofrecía parte de su desayuno a los niños mayores de su escuela para que le pusieran por escrito los versos que había compuesto. Habiendo perdido a su padre cuando era todavía niño, emprendió una travesura muy propia en un chico tan despierto y recorrió con un amigo diversas partes de España hasta que, habiéndoseles acabado el dinero y habiendo sido llevados ante un magistrado en Segovia por vender diversas bagatelas, se les envió de nuevo a casa, a Madrid.

Poco después de esta aventura nuestro joven poeta fue acogido bajo la protección de Jerónimo Manrique, obispo de Ávila, y comenzó a distinguirse por sus obras dramáticas, que el público recibía con gran aplauso, aunque su autor aún no había completado su formación, pues, después de este periodo, ingresó en la Universidad de Alcalá, donde se dedicó durante cuatro años a estudiar filosofía. Luego trabajó de secretario del duque de Alba y escribió su Arcadia en honor de ese mecenas, al que menciona con frecuencia en poemas de ocasión. Dejó este empleo al casarse con Isabel de Urbina, una dama (dice Pérez de Montalbán, amigo y biógrafo de Lope) bella sin artificio y virtuosa sin afectación. Un doloroso incidente interrumpió al poco su felicidad doméstica. Habiendo escrito algunos versos que ridiculizaban con viveza a una persona que se había tomado ciertas injuriosas libertades con su carácter, recibió un desafío a cambio de sus agudezas. En el duelo consiguiente hirió de gravedad a su adversario, con lo que se vio obligado a huir de los parientes de este y a refugiarse en Valencia. Vivió allí un tiempo considerable, pero su amor conyugal le devolvió a Madrid. Su mujer murió al año de su regreso.

La pena resultante le hizo abandonar sus estudios favoritos y embarcarse en la armada que se preparaba entonces para invadir Inglaterra. Tenía un hermano que servía en esa flota como teniente y que murió de un disparo en una lucha con varios buques holandeses, con lo que nuestro afligido poeta escribió celebrando sus virtudes, pues su corazón era especialmente dado a todo tipo de afectos generosos.

Después del desastre de la Armada, el desconsolado Lope de Vega regresó a Madrid y se empleó como secretario del marqués de Malpica, a quien dirige un agradecido soneto. De servir a este señor pasó a la casa del conde de Lemos, a 
quien celebra como poeta inimitable. Sin embargo, se inclinó de nuevo por abandonar el servicio de los poderosos para buscar los más apacibles deleites de la vida conyugal. Su segunda elección fue Juana de Guardo, de noble cuna y singular belleza. Esta dama le dio dos hijos: un niño que murió en la infancia y una niña, llamada Feliciana, que sobrevivió a su padre. Se dice que la muerte de este niño aceleró la de su mujer, a quien tuvo la desgracia de perder tras unos siete años de matrimonio.

Habiendo así experimentado lo precario de todo deleite humano, se dedicó a la vida religiosa y desempeñó todos los deberes de ella con la piedad más ejemplar, mientras seguía produciendo una asombrosa variedad de composiciones poéticas. $\mathrm{Su}$ talento y virtudes le hicieron obtener sin solicitarlos numerosos honores. El papa Urbano VIII le envió la cruz de Malta con el título de doctor en teología y le señaló un lugar distinguido en la cámara apostólica, favores por los cuales expresó su gratitud dedicándole la Corona trágica (un extenso poema sobre el destino de María Estuardo) a ese generoso pontífice.

A los setenta y tres años de edad sintió que le sobrevenía la muerte y se preparó para el trance con la mayor compostura y devoción. Sus últimas horas fue atendido por muchos de sus amigos íntimos, y particularmente por su mecenas, el duque de Sessa, a quien nombró albacea, dejándole a cargo de su hija Feliciana y de sus varios manuscritos. El modo en que se despidió del mundo fue muy tierno y emotivo. Le dijo a su discípulo y biógrafo, Montalbán, que la verdadera fama consistía en ser virtuoso y que trocaría encantado todos los aplausos que había recibido a cambio de poder añadir una sola acción virtuosa a las que había hecho en su vida. Expiró el 25 de agosto de 1635, tras bendecir a su hija y recibir la extrema unción de su religión.

El esplendor de su funeral igualó al respeto con que se le trató en vida. Su generoso mecenas, el duque de Sessa, invitó a él a los principales nobles del reino. La ceremonia se prolongó a lo largo de varios días y tres de los más celebrados ingenios sacros del momento predicaron sendos sermones en honor del difunto. Estos fueron impresos con las obras del poeta y se pueden considerar curiosos especímenes de la falsa elocuencia que dominaba en la época. Poco después de la muerte de este llorado bardo se publicó un volumen de versos encomiásticos, casi todos en español, escritos por más de ciento cincuenta de los personajes más distinguidos del país. A esta colección su amigo y discípulo Pérez de Montalbán añadió un relato de su vida y muerte que me ha servido de fuente principal en lo precedente. Un ingenioso viajero que ha publicado últimamente un volumen de cartas sobre la poesía española sugiere que el duelo en el que Lope de Vega participó estaba relacionado con el cortejo de su primera mujer, pero la versión que Montalbán da del caso salvaguarda el honor de la dama, cuya inocencia se ve además corroborada por un poema en su honor que escribió Pedro de Medina Medinilla y que está 
impreso con las obras de nuestro poeta, que aparece en él con el nombre de Belardo celebrando las excelencias de la difunta Isabel y lamentando su muerte.

Acerca de la persona y costumbres de Lope de Vega su amigo Montalbán solamente nos proporciona esta semblanza general: señala que su constitución era particularmente robusta y que la preservó en constante salud gracias a la templanza de sus costumbres; que en la conversación era suave y modesto, cortés con todos y particularmente galante con las damas; muy atento al servicio de los demás y descuidado en los propios. De su riqueza y caridad hablaré en otra nota. Los principales gastos en que incurría eran los relativos a libros y cuadros. De estos distribuyó algunos como legado a sus amigos íntimos: al duque de Sessa, un buen retrato de sí mismo; a mí, dice Montalbán, otro, pintado en su juventud, rodeado de perros, monos y otros monstruos, y escribiendo en medio de ellos sin hacer caso de su ruido.

Acerca de los honores que se concedieron a este extraordinario poeta su biógrafo afirma que no había persona eminente que visitara España que no buscara conocerle en persona; que los hombres le cedían el paso en las calles, mientras las mujeres le saludaban y bendecían cuando pasaba bajo sus ventanas. Si alguien puede merecer semejante homenaje por su incansable dedicación a la poesía, Lope de Vega ciertamente lo recibió con justicia. Declaró que escribió cinco pliegos al día y sus biógrafos, que han hecho un cálculo de esta cifra, concluyen que sus versos suman no menos de 21.316.000. Su patria ha publicado muy recientemente una elegante edición de sus poemas en diecinueve volúmenes en cuarto; sus obras dramáticas se añadirán después a esta colección y probablemente serán incluso más voluminosas.

Me centraré solo en las primeras. Entre sus poemas hay varias epopeyas, de las cuales las tres siguientes son las que me parecen más notables: 1. La Dragontea, 2. La hermosura de Angélica, 3. La Jerusalén conquistada. La Dragontea consta de diez cantos acerca de la última expedición y muerte de nuestro gran héroe naval Sir Francis Drake, a quien el poeta, influido por la excesiva parcialidad de su país, considera un pirata rapaz o incluso un dragón marino, como decide llamarle. Y baste señalar que le trata de manera consecuente con estos epítetos. En cuanto al poema sobre Angélica, parece haber sido compuesto emulando a Ariosto y se basa en una sugerencia de ese poeta. Fue escrito en la juventud del autor y contiene muchos elogios a su soberano Felipe II. Consta de veinte cantos y concluye con el regreso de Angélica junto a su amado Medoro. En lo que concierne a la Jerusalén conquistada, en ella secunda a Tasso, a quien menciona en el prefacio como autor de la primera parte de la historia que elige como tema. Dado el renombre de Lope de Vega había pensado ofrecerle al lector un resumen de este notabilísimo poema, pero como poeta épico me parece muy inferior a Tasso y a su paisano y contemporáneo, Ercilla, y no quiero hinchar estas ya extensas notas con una descripción 
dilatada de esta obra fallida. El autor profetiza al final de la misma que, aunque la desatienda su propio tiempo, la estimará la posteridad. Prueba singular de que incluso los autores más apreciados se inclinan frecuentemente a deplorar el tiempo que les tocó vivir. Si Lope de Vega se considera desatendido, ¿qué poeta podría jamás esperar verse satisfecho por los aplausos del público? Pero, para regresar a su Jerusalén conquistada, Ricardo II de Inglaterra y Alfonso VIII de Castilla son los héroes principales del poema, que contiene veinte cantos y se cierra con el desafortunado regreso de estos reyes aliados y con la muerte de Saladino. Fue impresa por primera vez en 1609, más de veinte años después de la primera aparición de la Jerusalén de Tasso.

Una de las peculiaridades más apreciables del carácter de Lope es la extrema generosidad con la que alaba los méritos de sus rivales. En su Laurel de Apolo celebra a todos los poetas eminentes de España y Portugal y dedica tanto a Camões como a Ercilla los más cálidos aplausos. Entre los pasajes más gustosos de este poema se encuentra la alabanza de su padre, quien fue, como el padre de Tasso, un poeta de talento considerable.

Entre las obras breves de Lope de Vega hay dos particularmente curiosas: un poema descriptivo sobre el jardín de su mecenas, el duque de Alba, y un soneto en honor de la Armada Invencible. El último puede considerarse un ejemplo perfecto de fanfarronería española: «Id y abrasad el mundo», dice el poeta, dirigiéndose a la poderosa flota, «que bien llevan / mis velas viento y alquitrán los tiros / que a mis suspiros y a mi pecho deban». Quizás esta muestra pueda ser igualada por un retrato de la personalidad de nuestro poeta con la que cerraré mi imperfecta semblanza. Es el de su amigo y biógrafo Montalbán, que al comienzo de su vida le otorga los siguientes títulos:

el doctor frey Lope Félix de Vega Carpio, portento del orbe, gloria de la nación, lustre de la patria, oráculo de la lengua, centro de la fama, asunto de la envidia, cuidado de la fortuna, Fénix de los siglos, príncipe de los versos, Orfeo de las ciencias, Apolo de las Musas, Horacio de los poetas, Virgilio de los épicos, Homero de los heroicos, Píndaro de los líricos, Sófocles de los trágicos y Terencio de los cómicos, único entre los mayores y mayor entre los grandes, y grande a todas luces $\mathrm{y}$ en todas materias.

3. Hayley: UN ENSAYO SOBRE POESÍA ÉPICA (pp. 85-86, vv. 301-318)

Si solo ideas humildes inspiran a los vates, si es enriquecerse el fin del escritor, que la Musa te muestre, bien que en clima diverso, riqueza, bello don de la rima en favor. ¡Mira el bardo adorado de España generosa, 
la Vega más sonora, la vena inagotable, desde honesta pobreza, su destino inicial - cuyo honor nunca ensucia la mancha de los vicios-, míralo, va ascendiendo en alas de Fortuna y ya casi alcanzando la opulencia real, pues con tan franca mano los nobles del país enriquecen y colman de dones al gran vate! Para él hierve de oro la roca de Pieria, para él fluyen las fuentes con dorado esplendor y nunca la Fortuna con un amor más justo confió sus regalos a persona mejor, pues con una corriente más pura, ancha y fuerte, su caridad supera a su copiosa canción.

\section{Hayley: UN ENSAYO SOBRE POESÍA ÉPICA (pp. 291-292)}

Para él fluyen las fuentes del dorado manantial. Sobre la gran riqueza que fluyó a manos de este poeta extraordinario, su amigo y biógrafo Montalbán ofrece una relación detallada. Este autor concluye que Lope de Vega ganó solamente con su obra dramática una suma casi igual a veinte mil libras esterlinas. Además, la ganancia procedente de los puestos que ostentó y de su pensión fue muy considerable. Esta opulencia fue muy aumentada por los más espléndidos ejemplos de liberalidad privada que se puedan contemplar. Recibió muchos y muy costosos presentes de varios personajes que no conocía personalmente y se le oyó decir, hablando de su generoso mecenas, que solo el duque de Sessa le había dado, en diferentes periodos de su vida, sumas que casi se elevaban a seis mil libras.

Debemos confesar que los nobles mecenas de la poesía inglesa no han igualado este ejemplo de munificencia española, incluso si admitimos como ciertas las anécdotas que trae la tradición sobre la generosidad de Lord Southampton para con Shakespeare, o de Sir Philip Sidney para con Spenser. Considerando la liberalidad por la que tan justamente se celebra nuestra nación, es notable que ningún poeta inglés haya sido enriquecido por nuestros soberanos, y eso que Spenser merecía absolutamente las recompensas de Isabel I, pues cantó sus alabanzas con un esfuerzo que debió de gratificar su orgullo y pues de todos los que han lisonjeado a los poderosos podemos considerarlo con justicia el más digno de ser premiado por ellos. Su canción era el tributo de su corazón y de su fantasía, y el sexo de su ídolo puede considerarse una purificación de su incienso de todo posible rastro de adulación servil. El descuido en que lo tuvo la vana, imperiosa y desagradecida Isabel parece más chocante cuando recordamos que su amable rival, la bella y desafortunada reina de Escocia, señaló su generosidad superior regalándole un magnífico servicio de mesa al poeta francés Ronsard. Este poeta abandonado fue 
una vez el favorito de Francia y quizás igualó a Lope de Vega en los honores recibidos: su soberano, Carlos IX, compuso unos elegantes versos en su alabanza y la ciudad de Toulouse le regaló una Minerva de plata maciza.

Si nuestros príncipes y nobles no han igualado a los de otros reinos en muestras de liberalidad a los grandes poetas del país, Inglaterra todavía puede preciarse de un ciudadano particular que mostró en este respecto un espíritu principesco: ninguna nación, antigua o moderna, puede producir un ejemplo de munificencia más noble que la pensión anual que Akenside recibió de Mr. Dyson, un tributo de generosa y afectuosa admiración que regaló a su merecido poseedor con toda consideración posible para hacerlo honorable tanto para él como para su mecenas.

Un escritor elegante y refinado que tiene buenas razones para quejarse se ha lamentado recientemente de que «la profesión literaria, con mucho la más laboriosa de todas, no produce ningún beneficio $\rangle^{28}$. La experiencia prueba sin lugar a dudas que tiene una tendencia generalizada a empobrecer a sus devotos y que los legisladores de los diversos países harían quizás bien, y en todo caso actuarían honrosamente, si corrigieran esta tendencia señalando pensiones públicas para los que se distingan de modo eminente en las diversas ramas de la ciencia. Sería sin duda posible encontrar un sistema que, sin ser una carga para la nación, fomentara su gloria protegiendo a los hombres de letras de los peligros frecuentemente asociados a su carrera, asegurando para aquellos que lo merecieran la tranquilidad y el honor necesarios, todo ello sin perjudicar la emulación ni destruir su independencia.

$28[N . T$.$] Hayley cita aquí a un reseñista anónimo de la Monthly Review, cuya identidad parece$ conocer: «It is a painful consideration that the profession of literature, by far the most laborious of any, leads to no real benefit or true glory whatsoever. Poetry, science, letters, when they are not made the sole business of life, may become its ornaments in prosperity, and its most pleasing consolation in change of fortune; but if a man addicts himself entirely to learning and hopes by that either to raise a family or to acquire what so many wish for and so few ever attain, an honourable retirement in a declining age, he will find when it is too late that he has mistaken his path, that other labours, other studies, are necessary, and that, unless he can assert his own independence in active life, it will avail him little to be favoured by the learned, esteemed by the eminent, or recommended even by kings» («Article VII» 1774: 286). 


\section{BIBLIOGRAFÍA}

«Article VII. The History of the Life of Nader Shah, King of Persia, [...] By William Jones, Esq.; Fellow of University College, Oxford, and of the Royal Societies at London and Copenhagen. 8vo. 6s. bound. Cadell. 1773» (1774). The Monthly Review or Literary Journal, 49, pp. 280-286.

Azara, José Nicolás de (ed.) (1765). Obras de Garcilaso de la Vega. Madrid: Imprenta Real de la Gaceta.

Azara, José Nicolás de (1782). «Artículos de cartas de don José Nicolás de Azara que servirán de prólogo». En Guillermo Bowles, Introducción a la historia natural y a la geografía física de España. Segunda edición corregida. Madrid: Imprenta Real, s.p.

Bacigalupo, Mario Ford (1979). «An Ambiguous Image: English Travel Accounts of Spain (1750-1787)». Dieciocho, 2, 1, pp. 21-42.

Baretti, Giuseppe Marco Antonio (1770). A Journey from London to Genoa, through England, Portugal, Spain, and France. London: Davies.

Baretti, Giuseppe Marco Antonio (1972). Opere scelte. Torino: Unione tipográficoeditrice torinese.

Bate, Jonathan (1997). The Genius of Shakespeare. London: Picador.

Bolufer Peruga, Mónica (2003). «Civilización, costumbres y política en la literatura de viajes a España en el siglo XvIII». Estudis, 29, pp. 255-300.

Bowles, Guillermo (1775). Introducción a la historia natural y a la geografía física de España. Madrid: Francisco Manuel de Mena.

Bruno, Paul W. (2010). Kant's Concept of Genius: Its Origin and Function in the Third Critique. London / New York: Bloomsbury.

Burkhard Mencke, Johann (1715-1726). Compendiöses Gelehrten Lexicon. Leipzig: Johann Friedrich Gleditsch und Sohn.

Cabo Aseguinolaza, Fernando (2003). «La dimensión geoliteraria de la historiografía literaria española». En Gabriella Menzel y Lászlo Scholz (eds.), El espacio en la narrativa moderna en lengua española. Budapest: Universidad Ëotvös Loránd, pp. 8-25.

Calderón de la Barca, Joseph (1796). «Carta apologética en defensa de Fr. D. Félix Lope de Vega Carpio y otros poetas cómicos españoles». Memorial Literario, 14, pp. 305-322.

Castillo, Francisco Javier (2003). «Sobre la literatura inglesa de viajes en el Siglo de las Luces: George Glas y sus apuntes sobre el teatro». Revista de Filología, 21, pp. 37-57.

CheCa Beltrán, José(1998). Razones del buen gusto: poética española del neoclasicismo. Madrid: CSIC.

Clarke, Edward (1763). Letters Concernig the Spanish Nation: Written at Madrid During the Years 1760 and 1761. London: T. Becket and P. A. De Hondt. 
Class, Monika (2012). Coleridge and the Kantian ideas in England, 1796-1817: Coleridge's Responses To German Philosophy. London-Oxford: Bloomsbury.

Comellas, Mercedes (2017). «La historia literaria española según John Bowring: "Observations on the state of religion and literature in Spain" (1819), "Poetical Literature of Spain" (1821-1822) y Ancient Poetry and Romances of Spain (1824)». En José Manuel González Herrán et alii (coords.), La Historia en la Literatura Española del siglo XIX. Barcelona: Sociedad de Literatura Española del siglo XIX / Universitat de Barcelona, pp. 395-416.

Cronegk, Johann Friedrick von (1761). Über die spanische Bühne und über die abgebrochnen Reden im Schauspiel. Erster Band. Anspach: Posch.

Dal Pozzo, Cassiano (2004). El diario del viaje a España del cardenal Francesco Barberini. Alessandra Anselmi (ed.). Ana Minguito (trad.). Aranjuez: Doce Calles.

DiEze, Johann Andreas (trad.) (1769). Luis José Velázquez de Velasco. Geschichte der Spanischen Dichtkunst; aus dem Spanischen übersetzt und mit Anmerkungen erläutert. Göttingen: Victoriuus Bossiegel.

Dillon, John Talbot (1780). Travels through Spain with a View to Illustrate the Natural History and Physical Geography of that Kingdom in a Series of Letters. London: G. Robinson.

Dillon, John Talbot (1781). Letters from an English Traveller in Spain in 1778 on the Origin and Progress of Poetry in that Kingdom, with Occasional Reflections on Manners and Customs, and Illustrations of the Romance Don Quixote. London: R. Baldwin.

Dillon, John Talbot (1782). Sketches on the Art of Painting, with a Description of the Most Capital Pictures in the King of Spain's Palace at Madrid. London: R. Baldwin.

Dillon, John Talbot (1788). History of the Reign of Peter the Cruel, King of Castile and León. London: W. Richardson.

Dillon, John Talbot (1800). Alphonso and Eleanora, or The Triumphs of Valour and Virtue. 2 vols. London: J. Barker.

ECK, Reimer (1997). «Entstehung und Umfang der spanischen Büchersammlung der Universitätsbibliothek Göttingen im 18. Jahrhundert». En Hans Juretschke (ed.), Zum Spanienbild der Deutschen in der Zeit der Aufklärung. Münster: Aschendorff, pp. 87-132.

Entrambasaguas, Joaquín de (1941). «El lopismo de Moratín». Revista de Filología Española, 25, pp. 1-45.

FArinelli, Arturo (1936). Lope de Vega en Alemania. Barcelona: Bosch.

Flavigny, Vicomte de (trad.) (1776). Guillaume Bowles. Introduction à l'Histoire Naturelle et à la Géographie Physique de l'Espagne. Paris: L. Cellot et Jombert.

García Aguilar, Ignacio (2013). «La "poesía de hoy” en los Orígenes (1754) de Luis José Velázquez: periferia, heterodoxia y canon en los albores de la historiografía literaria». Versants, 60, pp. 43-55.

Glas, George (1764). The History of the Discovery and Conquest of the Canary Islands [...] to Which is Added a Description of the Canary Islands. London: Dodsley and Durham. 
GonzÁlez García, Manuel José (1997). «Lessings Kenntnisse der spanischen Literatur und Kultur». En Hans Juretschke (ed.), Zum Spanienbild der Deutschen in der Zeit der Aufklärung. Münster: Aschendorf, pp. 133-148.

Guerrero, Ana Clara (1989). «Las relaciones hispano-británicas tras la paz de Versalles (1783)». Espacio, Tiempo y Forma, 2, pp. 13-28.

HäGG, Thomas (2012). The Art of Biography in Antiquity. Cambridge: Cambridge University Press.

Hallam, Henry (1837). Introduction to the Literature of Europe in the Fifteenth, Sixteenth, and Seventeenth Centuries. London: John Murray.

Hayley, William (1780). An Essay on History: in Three Epistles to Edward Gibbon. London: Dodsleyin.

Hayley, William (1781). An Essay on Painting, in a Poetical Epistle to an Eminent Painter. Dublin: Pat Byrne.

Hayley, William (1782). An Essay on Epic Poetry in Five Epistles. London: J. Dodsley.

Hayley, William (1793). A Philosophical, Historical, and Moral Essay on Old Maids. London: Cadell.

Hayley, William (1811). Three Plays: with a Preface, Including Dramatic Observations of the Late Lieutenant-General Burgoyne. Chichester: William Mason.

Hayley, William (1823). Memoirs of the Life and Writings of William Hayley, Esq: The Friend and Biographer of Cowper, Written by Himself. London: H. Colburn and Company.

Herder, Johann Gottfried (2014). Kritische Wälder, Berliner Ausgabe. Bernhard Suphan (ed.) [1878]. Berlin: Contumax Hofenberg.

Holland, Lord (Henry Richard) (1806). Some Account of the Life and Writings of Lope Félix de Vega Carpio. London: Longman, Hurst, Rees, and Orme.

KaYser, Wolfgang (1945). Die iberische Welt im Denken J. C. Herders. Hamburg: IberoAmerikanisches Institut.

KRIs, Ernst y Otto KURz (1987). L'Image de l'artiste. Légende, mythe et magie: un essai historique. Michèle Hechter (trad.). Marseille: Rivages, 1987.

Lessing, Gotthold Ephraim (1993). Dramaturgia de Hamburgo. Paolo Chiarini (introd.). Madrid: Asociación de Directores de Escena de España.

LóPEZ, François (1976). Juan Pablo Forner (1767-1797) et la crise de la conscience espagnole au XVIII e siècle. Bordeaux: Biscaye Frères.

Marino, Nancy (2014). «John Talbot Dillon and His Letters on the Origin of Spanish Poetry: a Reconsideration». Dieciocho 37, 2, pp. 187-210.

Martín Puya, Ana Isabel (2014). Edición y estudio de las notas de Azara a Garcilaso (1765). [Tesis doctoral inédita]. Córdoba: Universidad de Córdoba $<$ https://www.researchgate.net/profile/Ana_Isabel_Puya/publication/294088201 Edicion_y_estudio_de_los_comentarios_de_Azara_a_Garcilaso_1765/links/ 56bde77108ae44da37f88234.pdf>.

Menéndez Pelayo, Marcelino (2012). Historia de las Ideas Estéticas en España. Santander: Real Sociedad Menéndez Pelayo-Universidad de Cantabria. 
Mestre, Antonio (1997). «Mayans’ Beitrag zum deutschen Spanienhild im 18. Jahrhundert». En Hans Juretschke (ed.), Zum Spanienbild der Deutschen in der Zeit der Aufklärung. Münster: Aschendorf, pp. 60-86.

Milizia, Francesco (trad.) (1783). Guglielmo Bowles. Introduzione alla storia naturale e alla geografia fisica di Spagna di Guglielmo Bowles, pubblicata e commentata dal cavaliere don Giuseppe Niccola d'Azara. Parma: Stamperia Reale.

Nasarre, Blas (1992). Disertación o prólogo sobre las comedias de España. Jesús Cañas Murillo (ed.). Cáceres: Universidad de Extremadura.

OlezA, Joan (1996). «Claves románticas para la primera interpretación moderna del teatro de Lope de Vega». Anuario Lope de Vega, 1, pp. 119-135.

Peers, E. Allison (1940). A History of the Romantic Movement in Spain. Cambridge: Cambridge University Press.

Pérez de Montalbán, Juan (2001). «Fama póstuma a la vida y muerte del doctor frey Lope Félix de Vega Carpio». En Enrico di Pastena (ed.), Juan Pérez de Montalbán, Fama póstuma a la vida y muerte del doctor frey Lope Félix de Vega Capio y elogios panegíricos a la inmortalidad de su nombre. Pisa: ETS, pp. 17-38.

Pujante, Angel-Luis Pujante (2001). «Shakespeare Or/And...? The Spanish Counterpart in the Eighteenth and Nineteenth Centuries». En Boika Sokolova and Evgenia Pancheva (eds.), Renaissance Refractions. Essays in Honour of Alexander Shurbanov. Sofia: St. Kliment Ohridski University Press, pp. 157-169.

Rivero Iglesias, Carmen (2010). «Lessing y el Arte nuevo de hacer comedias en la Alemania del siglo XVIII». En Germán Vega García-Luengos, Héctor Urzáiz Tortajada (coords.), Cuatrocientos años del «Arte nuevo de hacer comedias» de Lope de Vega: actas selectas del XIV Congreso de la Asociación Internacional de Teatro Español y Novohispano de los Siglos de Oro, Olmedo, 20 al 23 de julio de 2009. Valladolid: Universidad de Valladolid, t. 2, pp. 845-856.

RoBertson, Ian (1976). Los curiosos impertinentes: viajeros ingleses por España desde la ascensión de Carlos III hasta 1855. Madrid: Editora Nacional.

Romero Tobar, Leonardo (2010). «El Romanticismo y las primeras historias de las literaturas ibéricas». En Francisco Lafarga, Luis Pegenaute y Enric Gallén (eds.), Interacciones entre las literaturas ibéricas. Berna: Peter Lang, pp. 463-480.

Rossi, Giuseppe Carlo (1967). Estudios sobre las letras en el siglo XVIII. Madrid: Gredos.

Sala Valldaura, Josep Maria (2000). «Preceptiva, crítica y teatro: Lope de Vega en el siglo XVIII». Anuario Lope de Vega, 6, pp. 164-193.

Schmid, Christian (1767). Theorie der Poesie nach den neuesten Grundsätzen und Nachrichten von den besten Dichtern nach den angenommenen Urtheilen. Leipzig: Sigfried Lebrecht Crusius.

Shelley, Mary (2015). Cervantes y Lope de Vega. Vidas paralelas. Antonio Sánchez Jiménez (ed. y trad.). Barcelona: Calambur.

«Sketch of the Life and Character of the Famous Poet Lope de Vega; from a Book Entitled Letters from an English Traveller in Spain, etc.» (1800). En The Annual Register, or a View of the History, Politics, and Literature, for the Year 1781. London: Dodsley, pp. 33-36. 
Spang, Kurt (2010). «El Arte nuevo y la Dramaturgia de Hamburgo: los manifiestos dramatúrgicos de Lope y de Lessing». Rilce, 27, 1, pp. 257-266.

Swinburne, Henry (1787). Travels through Spain in the Years 1775 and 1776. London: J. Davis.

Tiemann, Hermann (1939). Lope de Vega in Deutschland. Hamburg: Lütcke \& Wulff.

Turner, Katherine (2001). British Travel Writers in Europe, 1750-1800. Authorship, Gender and National Identity. Aldershot: Ashgate.

VEGA, Miguel Ángel (1997). «Herders Spanienbild und dessen gelehrte Quellen». En Hans Juretschke (ed.), Zum Spanienbild der Deutschen in der Zeit der Aufklärung. Münster: Aschendorf, pp. 149-172.

VelázQuez, Luis José (1754). Orígenes de la poesía castellana. Málaga: Francisco Martínez de Aguilar.

Voltaire (1880). Euvres complètes de Voltaire. Vol. 30. Mélanges. Louis Moland (ed.). Paris: Garnier frères.

Wiffen, Jeremiah H. (1823). Works of Garcilaso de la Vega, Surnamed the Prince of Castilian Poets, Translated into English Verse; with a Critical and Historial Essay on Spanish Poetry and a Life of the Author. London: Hurst, Robinson and Co.

Recibido: $22 / 04 / 208$

Aceptado: 21/05/2018 


\section{(2)}

\section{EL LOPISMO INGLÉS DEL SIGLO XVIII: \\ Sir John Talbot Dillon (1739-1805) y William Hayley (1745-1820)}

RESUMEN: Las opiniones sobre Lope de Vega de la Inglaterra de finales del siglo XVIII resultan sumamente importantes para comprender no solo la evolución de la imagen del Fénix en este país, sino para apreciar hasta qué punto Lope se convirtió en caballo de batalla de una polémica sobre las reglas y el buen gusto que tuvo extensión europea. Para ilustrar este conflicto, nuestro trabajo examina las opiniones sobre Lope de Vega de dos hispanistas dieciochescos, John Talbot Dillon (1739-1805) y William Hayley (17451820). Estudiándolos en el contexto en que se compusieron, y contrastando sus fuentes y criterios, explicamos el sentido e importancia de estos textos en su ámbito europeo, y ofrecemos en apéndice una traducción de los mismos, para que los especialistas los puedan comparar con los trabajos de los célebres lopistas ingleses del siglo XIX (Lord Holland, Shelley, etc.).

Palabras Clave: Lope de Vega, John Talbot Dillon, William Hayley, lopismo inglés, Herder, buen gusto.

\section{EIGHTEENTH-CENTURY LOPE DE VEGA STUDIES: \\ SiR John TALBOT DILLON (1739-1805) aND WILLIAM HAYLEY (1745-1820)}

ABSTRACT: English opinions about Lope de Vega during the last quarter of the eighteenth century are extremely important to understand not only how Lope's image in this country evolved, but also to appreciate to what extent Lope became a battlefield in the Europeanwide controversy about rules and good taste. To illustrate this conflict, the present article examines the opinions about Lope that we can find in the work of two eighteenth-century Hispanists, John Talbot Dillon (1739-1805) and William Hayley (1745-1820). Studying them in the context in which they were written, and contrasting their sources and criteria, we explain the meaning and importance of these texts in their European context, and we offer in an appendix a translation so that specialists can compare them with the work of the well-known English lopistas of the nineteenth century (Lord Holland, Shelley, etc.).

KEYWords: Lope de Vega, John Talbot Dillon, William Hayley, english lopismo, Herder, good taste. 


\section{Edad de Oro. Revista de Filología Hispánica}

ISSN: 0212-0429 - ISSNe: 2605-3314 <https://revistas.uam.es/edadoro/index>

Edad de Oro es uno de los máximos referentes en el área de investigación en Filología Hispánica, especialmente de los siglos XVI y XVII. Goza de un amplio reconocimiento en el ámbito académico internacional. Desde 1982 publica ininterrumpidamente, con una periodicidad anual, colaboraciones científicas de los principales especialistas de diversos centros nacionales y extranjeros. Con un público compuesto esencialmente por investigadores y expertos de todo el mundo, se dirige a cualquier persona interesada en las nuevas corrientes de los estudios humanísticos de su campo.

Dirección:

María Jesús Zamora Calvo

(Univ. Autónoma de Madrid)

Subdirección:

José Antonio Llera Ruiz

(Univ. Autónoma de Madrid)

Secretaría:

Raquel Arias Careaga

(Univ. Autónoma de Madrid)

Consejo de redacción:

Cecilia López-Ridaura

(ENES. Morelia / Univ. Nacional

Autónoma de México)

José Luis Ocasar Ariza

(Univ. Autónoma de Madrid)

Rocío Pérez Gironda

(Univ. Autónoma de Madrid)

Carolina Fernández Cordero

(Iberoamericana-Vervuert)

Admisión de originales:

María Jesús Zamora Calvo

Edad de Oro

Universidad Autónoma de Madrid

Facultad de Filosofía y Letras

Departamento de Filología Española

Campus Cantoblanco

28049 Madrid (España)

Tfno. (+34) 914976886

Correo-e: mariajesus.zamora@uam.es

Distribución, suscripción y venta:

Servicio de Publicaciones de la UAM

Universidad Autónoma de Madrid

28049 Madrid (España)
Intercambio de publicaciones:

Biblioteca de Humanidades

Universidad Autónoma de Madrid

28049 Madrid (España)

Comité científico:

Carlos Alvar (Université de Gèneve)

Ignacio Arellano (Univ. de Navarra)

Alberto Blecua

(Univ. Autónoma de Barcelona)

Jean Canavaggio

(Université Paris Nanterre)

Aurora Egido (Univ. de Zaragoza)

Víctor García de la Concha (RAE)

Luciano García Lorenzo (CSIC)

Joaquín González Cuenca

(Univ. de Castilla la Mancha)

Agustín de la Granja López

(Univ. de Granada)

Begoña López Bueno (Univ. de Sevilla)

Michel Moner

(Universitè Toulouse - Jean Jaurès)

Joan Oleza (Univ. de Valencia)

Alfonso Rey

(Univ. de Santiago de Compostela)

Lina Rodríguez Cacho

(Univ. de Salamanca)

Leonardo Romero Tobar

(Univ. de Zaragoza)

Aldo Ruffinatto

(Università degli Studi di Torino)

Lía Schwartz

(City University of New York)

Han colaborado en este volumen:

Departamento de Filología Española

(UAM)

Facultad de Filosofía y Letras (UAM)

Edad de Oro se recoge en las siguientes bases de datos y directorios: DICE; HLAS; MLA International Bibliography; PIO; ISOC-CSIC; DIALNET; SUMARIS CBUC; ULRICH'S.

Se encuentra evaluada en: SCOPUS: Q2; SCImago: SJR 2017 0.11, H Index 4; ERIH Plus: category A; CIRC: categoría C; RESH: 0.162; MIAR: ICDS 2017 10.0; CARHUS Plus+: C; LATINDEX. 


\section{EDAD DE ORO}

Revista de Filología Hispánica XXXVII

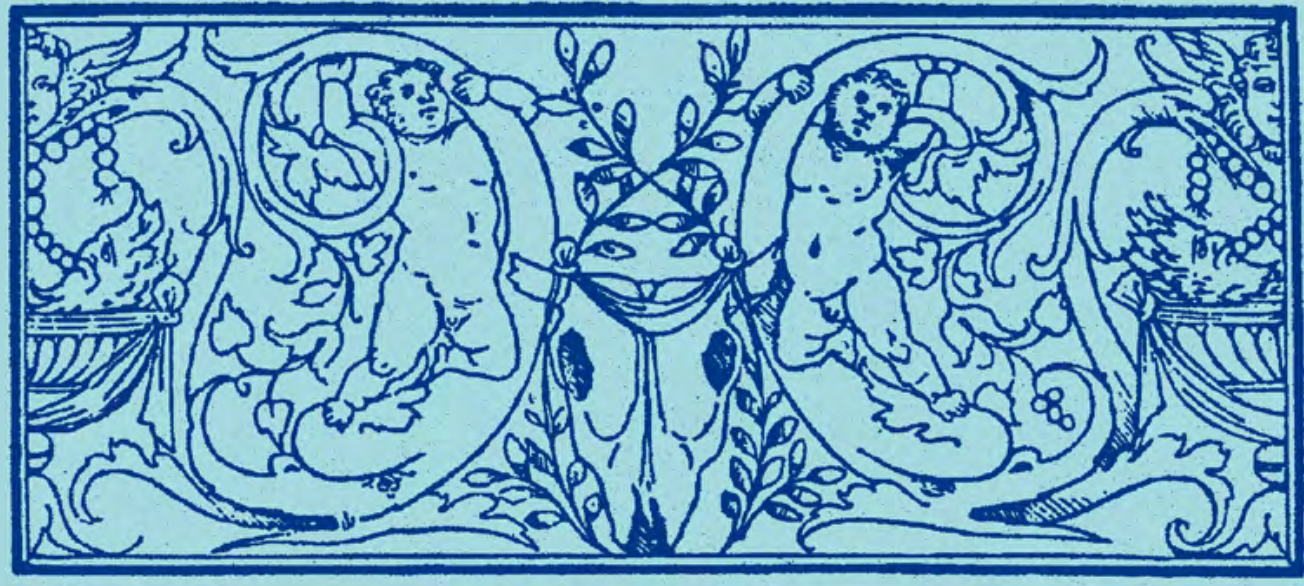

\section{DEPARTAMENTO DE FILOLOGÍA ESPAÑOLA}

EDICIONES DE LA UNIVERSIDAD AUTÓNOMA DE MADRID 